Journal of Tropical Ecology

http://journals.cambridge.org/TRO

Additional services for Journal of Tropical Ecology:

Email alerts: $\underline{\text { Click here }}$

Subscriptions: $\underline{\text { Click here }}$

Commercial reprints: $\underline{\text { Click here }}$

Terms of use : $\underline{\text { Click here }}$

\title{
Arbuscular mycorrhizas increase survival, precocity and flowering of herbaceous and shrubby species of early stages of tropical succession in pot cultivation
}

Artur Berbel Lirio Rondina, Luis Eduardo Azevedo Marques Lescano, Ricardo de Almeida Alves, Enio Massao Matsuura, Marco Antonio Nogueira and Waldemar Zangaro

Journal of Tropical Ecology / Volume 30 / Issue 06 / November 2014, pp 599 - 614

DOI: 10.1017/S0266467414000509, Published online: 26 September 2014

Link to this article: http://journals.cambridge.org/abstract S0266467414000509

How to cite this article:

Artur Berbel Lirio Rondina, Luis Eduardo Azevedo Marques Lescano, Ricardo de Almeida Alves, Enio Massao Matsuura, Marco Antonio Nogueira and Waldemar Zangaro (2014). Arbuscular mycorrhizas increase survival, precocity and flowering of herbaceous and shrubby species of early stages of tropical succession in pot cultivation. Journal of Tropical Ecology, 30, pp 599-614 doi:10.1017/S0266467414000509

Request Permissions : $\underline{\text { Click here }}$ 


\title{
Arbuscular mycorrhizas increase survival, precocity and flowering of herbaceous and shrubby species of early stages of tropical succession in pot cultivation
}

\author{
Artur Berbel Lirio Rondina*, $\uparrow$, Luis Eduardo Azevedo Marques Lescano*, $\dagger$, \\ Ricardo de Almeida Alves*, $\dagger$, Enio Massao Matsuura*, $\uparrow$, Marco Antonio Nogueira $§, \ddagger$ and \\ Waldemar Zangaro*,, 1
}

\footnotetext{
* Universidade Estadual de Londrina, Centro de Ciências Biológicas, Departamento de Biologia Animal e Vegetal, 86051-990, Londrina, PR, Brazil

† Programa de Pós-Graduação em Ciências Biológicas, Departamento de Biologia Animal e Vegetal, Universidade Estadual de Londrina, PR, Brazil

¥ Programa de Pós-Graduação em Microbiologia, Departamento de Microbiologia, Universidade Estadual de Londrina, PR, Brazil

$\S$ Embrapa Soja, PO Box 231, 86001-970, Londrina, PR, Brazil

(Received 3 April 2014; revised 12 August 2014; accepted 13 August 2014)
}

\begin{abstract}
Arbuscular mycorrhizal fungi (AMF) are an important biotic factor that influences tropical ecological succession and differently affect the woody species belonging to different successional stages. However, little is known about the influence of AMF on growth and reproduction of herbaceous and shrubby species of early phases of tropical succession. Thus, we assessed the effect of AMF on the development of 27 heliophilous herbaceous and shrubby tropical species. Plants were grown in greenhouse, in low- and high-fertility soils, with or without AMF, for 100 d. Most species grown with AMF exhibited high root infection intensity $(\approx 80 \%)$, irrespective of soil fertility. In the low-fertility soil, non-mycorrhizal plants exhibited about $88 \%$ less shoot dry mass (SDM) than mycorrhizal plants, and AMF were crucial for the survival of most species. Non-mycorrhizal plants also had lower relative growth rate (RGR), total leaf area (TLA), leaf area expansion (LAE) and total root length (TRL). Six species flowered in the low-fertility soil, and flowering increased with AMF in one plant species and four species only flowered when mycorrhizal. In the high-fertility soil, non-mycorrhizal plants exhibited about 13\% less SDM than mycorrhizal plants and also exhibited lower TLA, LAE, and nutrient concentrations in shoots. On the other hand, no major changes were observed for RGR, TRL and root dry mass for most of the species. Sixteen plant species flowered in the high-fertility soil, but most had earlier (11) and more abundant (10) flowering when mycorrhizal. Thus, AMF have different influences on the survival, growth and flowering of herbaceous and shrubby tropical species, depending on soil fertility: in low-fertility soil, AMF especially affect the survival, growth and flowering, whereas in high-fertility soil, AMF mainly influence the shoot nutrient concentrations and flowering.
\end{abstract}

Key Words: carbon use, fine roots, mycorrhizal infection, nutritional status, reproduction, seedling growth

\section{INTRODUCTION}

Heliophilous herbaceous and shrubby species typically colonize and dominate early successional sites in the tropical region. Over time, these plants are replaced by woody species that have a short lifespan, are shadeintolerant and which will also be reduced in abundance in the community when shade-tolerant species start to get established. These latter species typically have a long lifespan and predominate in the late stages of the succession (Guariguata \& Ostertag 2001). According

\footnotetext{
${ }^{1}$ Corresponding author. Email: wzangaro@uel.br
}

to Zangaro et al. (2000), arbuscular mycorrhizal fungi (AMF) are one of the main biotic factors involved in the establishment of plants during succession in the tropics. These fungi establish symbiosis with more than $80 \%$ of terrestrial plants (Smith \& Read 2008) and their hyphae increase considerably the amount of surrounding soil that can be explored for nutrient acquisition (Smith et al. 2011). As a result, mycorrhizal plants produce more biomass, flowers and seeds than non-mycorrhizal plants (Koide \& Dickie 2002, Stanley et al. 1993). In return, AMF receive photoassimilates from the host for their metabolism, production of internal and external hyphae and propagation structures (Smith \& Read 2008). 
Plant species belonging to different successional groups have different relationships with AMF, since higher densities of spores in soil (Mangan et al. 2004, Stürmer \& Siqueira 2011) and higher intensity of root infection (Zangaro et al. 2012a, 2013, 2014) have been found in sites colonized by plants at early successional stages, like herbaceous and shrubby species, compared with sites colonized by woody species at later stages. Such high maintenance of AMF by early-successional plant species can be a crucial condition for sustaining their high nutritional demands, survival and growth especially in low-fertility soils (Zangaro et al. 2013). Although lowfertility soils are common at the beginning of tropical succession, this process can also occur in fertile or fertilized soils, such as abandoned agricultural fields, where plants may not be reliant on AMF for their nutritional requirements. When plants colonized by AMF grow in high-fertility soils, the energetic cost of the symbiosis can be greater than the nutritional benefits, leading to plant growth depression (Johnson et al. 1997). Many studies have shown that plants grown in high-fertility soils, especially phosphorus-rich soils may decrease AMF root infection (Grman 2012, Johnson 2010, Johnson et al. 1997) to reduce the $C$ expense. However, Zangaro et al. (2013) quantified high AMF infection intensity (about $90 \%$ in roots of herbaceous and shrubby plants that grew spontaneously in a tropical abandoned agricultural field, which contained high levels of phosphorus and where soybean was cultivated $5 \mathrm{y}$ before. It is possible that this high maintenance of AMF in roots may provide nutritional benefits to this plant functional group even in fertile soils, since AMF increase mineral nutrient transfer in roots that provide high amounts of carbohydrates (Kiers et al. 2011).

Several studies have been conducted assessing the importance of AMF on the growth and reproduction of herbaceous and shrubby species of temperate regions, which predominate in several stages of the succession in prairie and grassland ecosystems (Busby et al. 2011, Klironomos 2003, Koide \& Dickie 2002, Wilson \& Hartnett 1998). However, little is known on the importance of AMF for vegetative and reproductive development of heliophilous herbaceous and shrubby tropical species that occur in the early-successional stages in both low- and high-fertility soils. Therefore, a trial was carried out to assess the influence of AMF on the growth and flowering of 27 herbaceous and shrubby earlysuccessional species grown in a low- and high-fertility soil. We hypothesized that (1) plants exhibit high levels of AMF root infection in both soils; (2) mycorrhizal plants exhibit higher shoot dry mass than non-mycorrhizal plants in low-fertility soil, but lower or not different shoot dry mass in high-fertility soil; (3) AMF are crucial for plant survival in low-fertility soil, but not in high-fertility soil; (4) AMF increase plant flowering in both levels of soil fertility.

\section{METHODS}

\section{Plant species}

Seeds were collected during 2010, according to their availability, at sites with a predominance of herbaceous and shrubby vegetation (e.g. pastures, abandoned fields under initial succession, border of forest fragments) in the municipality of Londrina $\left(23^{\circ} 27^{\prime} \mathrm{S}, 51^{\circ} 15^{\prime} \mathrm{W}\right)$, Paraná State, Southern Brazil, then stored at $5^{\circ} \mathrm{C}$ until the sowing, performed in February 2011. All species were identified and characterized according to Kranz et al. (2009), Leitão Filho et al. (1972) and Lorenzi (2000) (Table 1). We considered the plant species as belonging to the same ecological group because they naturally occur and grow at the same time in earlier-successional sites and have very similar niches.

\section{Soil sampling and preparation}

The soil was a clay Rhodic Ferralsol (FAO 1994), collected at the Universidade Estadual de Londrina (State University of Londrina), at sites with low and high fertility. The highfertility soil was taken from a former garden that received constant organic manure, had been abandoned for 10 $\mathrm{y}$ and had this practice ended prior to abandonment. Currently, this area is predominantly colonized with Paspalum notatum Flüggé and other herbaceous species. The low-fertility soil was collected about $250 \mathrm{~m}$ away from the sample points of high-fertility soil, at a site that had the A horizon and part of the B horizon removed $25 \mathrm{y}$ ago, resulting in a low-fertility soil now colonized by $P$. notatum. At each site, four points, $20 \mathrm{~m}$ apart, were randomly selected and soil samples were taken at 0-10 cm depth, homogenized and sieved ( $4 \mathrm{~mm})$. These soils were sterilized with steam for $72 \mathrm{~h}$ to eliminate AMF propagules. After that, the soils were transferred to plastic pots $\left(1500 \mathrm{~cm}^{3}\right)$, rewetted and kept moist and without plants for $150 \mathrm{~d}$. To restore the original microbial flora of the sterilized soils, we added $100 \mathrm{~mL}$ of a filtrate obtained from each of the original fresh soils, without AMF propagules, every $30 \mathrm{~d}$ until planting. The soils were chemically analysed for mineral $\mathrm{N}$ according to Keeney \& Nelson (1982), for micronutrients according to Defilippo \& Ribeiro (1997) and for other attributes according to Pavan et al. (1992) (Table 2).

\section{AMF inoculum preparation, inoculation, sowing and early growth}

A mixture of spores of AMF native species was obtained from the rhizosphere of $P$. notatum and other herbaceous species in the lawn of State University of Londrina to 
Table 1. Habit and lifespan of the studied tropical plant species commonly found at early successional sites in southern Brazil.

\begin{tabular}{|c|c|c|}
\hline Species & Habit & Lifespan \\
\hline \multicolumn{3}{|l|}{ Amaranthaceae } \\
\hline Amaranthus hybridus L. & Herbaceous & Annual \\
\hline \multicolumn{3}{|l|}{ Asclepiadaceae } \\
\hline Asclepias curassavica L. & Herbaceous & Annual \\
\hline \multicolumn{3}{|l|}{ Asteraceae } \\
\hline Baccharis sp. & Shrubby & Perennial \\
\hline Hypochaeris brasiliensis (Less.) Hook. \& Arn. & Herbaceous & Annual \\
\hline Porophyllum ruderale (Jacq.) Cass. & Herbaceous & Annual \\
\hline Vernonia cognata Less. & Subshrubby & Perennial \\
\hline Vernonia polyanthes Less. & Shrubby & Perennial \\
\hline \multicolumn{3}{|l|}{ Bignoniaceae } \\
\hline Tecoma stans (L.) Juss. ex Kunth & Shrubby & Perennial \\
\hline \multicolumn{3}{|l|}{ Cucurbitaceae } \\
\hline Momordica charantia L. & Herbaceous & Annual \\
\hline \multicolumn{3}{|l|}{ Fabaceae } \\
\hline Chamaecrista nictitans (L.) Moench & Herbaceous or subshrubby & Perennial \\
\hline Crotalaria incana $\mathrm{L}$. & Herbaceous or subshrubby & Annual \\
\hline Indigofera hirsuta L. & Herbaceous & Annual \\
\hline Mimosa invisa Mart. ex Colla & Subshrubby & Perennial \\
\hline Senna obtusifolia (L.) H.S. Irwin \& Barneby & Subshrubby & Annual \\
\hline \multicolumn{3}{|l|}{ Lamiaceae } \\
\hline Hyptis spicigera Lam. & Herbaceous & Annual \\
\hline Leonotis nepetifolia (L.) R. Br. & Herbaceous or subshrubby & Annual \\
\hline Leonurus sibiricus L. & Herbaceous & Annual \\
\hline \multicolumn{3}{|l|}{ Malvaceae } \\
\hline Sidastrum micranthum (A. St.-Hil) Fryxell & Subshrubby & Perennial \\
\hline \multicolumn{3}{|l|}{ Poaceae } \\
\hline Cenchrus echinatus L. & Herbaceous & Annual \\
\hline Chloris elata Desv. & Herbaceous & Perennial \\
\hline Digitaria insularis (L.) Fedde & Herbaceous & Perennial \\
\hline Eragrostis pilosa (L.) P. Beauv. & Herbaceous & Annual \\
\hline Melinis minutiflora P. Beauv. & Herbaceous & Perennial \\
\hline Melinis repens (Willd.) Zizka & Herbaceous & Annual \\
\hline Pennisetum purpureum Schumach. & Herbaceous & Perennial \\
\hline Sorghum arundinaceum (Desv.) Stapf & Herbaceous & Annual \\
\hline \multicolumn{3}{|l|}{ Solanaceae } \\
\hline Solanum viarum Dunal & Herbaceous & Annual \\
\hline
\end{tabular}

preparation of AMF soil inoculum. These spores were removed from soil by wet sieving, inoculated in roots of $P$. notatum and cultivated for 5 mo in pots with previously sterilized soil.

Each plant species was grown in the combination of soil fertility (low and high) with mycorrhizal condition (with and without AMF), in five replicates. The cultivation pots had a volume of $1500 \mathrm{~cm}^{3}$. In half of the cultivation pots containing low- and high-fertility soils, $2 \mathrm{~g}$ of fresh AMF soil inoculum (with approximately 1430 spores, along with colonized roots and hyphae) were added in a hole in the centre of the pot, $2 \mathrm{~cm}$ below the surface. In the other half of the pots, $2 \mathrm{~g}$ of the AMF soil inoculum previously sterilized (control group) were added in the hole. About 20 seeds of each plant species were sown in the hole on top of the soil inoculum and covered with $1 \mathrm{~cm}$ of the respective soil. Three days after emergence, five seedlings from each pot were collected for evaluation of the initial dry biomass to be used in the estimation of the relative growth rate. Seedlings were thinned to one per pot and kept in a greenhouse for $100 \mathrm{~d}$, under $75 \%$ sunlight, without air temperature control and received water daily. During the growth period, the time to flowering was recorded.

\section{Plant growth, flowering and nutrient concentration}

After $100 \mathrm{~d}$ of growth in the greenhouse, plants were separated into shoot and root. The total root length (Tennant 1975), number of flowers and total leaf area 
Table 2. Mean $( \pm S D)$ for chemical attributes of the substrates used for plant growth from low- and high-fertility soils. Means followed by the same letter do not differ by Student's $t$-test at $\mathrm{P}<0.05$ ( $n=$ 4). Mineral $\mathrm{N}=$ ammonium + nitrate. $\mathrm{w}=$ Walkley-Black method; $\mathrm{x}=$ extraction with $2 \mathrm{M} \mathrm{KCl} ; \mathrm{y}=$ extraction with Mehlich-1; $\mathrm{z}=$ extraction with $1 \mathrm{M} \mathrm{KCl}$.

\begin{tabular}{|c|c|c|}
\hline & Low-fertility soil & High-fertility soil \\
\hline$\overline{\mathrm{pH}}\left(\mathrm{CaCl}_{2}\right)$ & $4.90 \pm 0.08 b$ & $5.20 \pm 0.06 \mathrm{a}$ \\
\hline $\mathrm{H}^{+}+\mathrm{Al}^{+3}\left(\mathrm{cmol}(+) \mathrm{L}^{-1}\right)$ & $4.78 \pm 0.20 b$ & $5.45 \pm 0.20 \mathrm{a}$ \\
\hline $\mathrm{C}(\%)^{\mathrm{w}}$ & $0.66 \pm 0.42 b$ & $2.02 \pm 0.14 \mathrm{a}$ \\
\hline Mineral $\mathrm{N}\left(\mathrm{mg} \mathrm{kg}^{-1}\right)^{\mathrm{x}}$ & $9.72 \pm 4.11 b$ & $19.1 \pm 1.91 \mathrm{a}$ \\
\hline $\mathrm{P}\left(\mathrm{mg} \mathrm{L}^{-1}\right)^{\mathrm{y}}$ & $0.89 \pm 0.10 b$ & $36.0 \pm 3.01 \mathrm{a}$ \\
\hline $\mathrm{K}\left(\mathrm{cmol}(+) \mathrm{L}^{-1}\right)^{\mathrm{y}}$ & $0.34 \pm 0.01 b$ & $0.88 \pm 0.15 \mathrm{a}$ \\
\hline $\operatorname{Mg}\left(\mathrm{cmol}(+) \mathrm{L}^{-1}\right)^{\mathrm{Z}}$ & $2.00 \pm 0.18 \mathrm{a}$ & $1.97 \pm 0.14 \mathrm{a}$ \\
\hline $\mathrm{Ca}\left(\mathrm{cmol}(+) \mathrm{L}^{-1}\right)^{\mathrm{Z}}$ & $3.09 \pm 0.10 b$ & $8.22 \pm 0.31 \mathrm{a}$ \\
\hline $\mathrm{Al}\left(\mathrm{cmol}(+) \mathrm{L}^{-1}\right)^{\mathrm{Z}}$ & $0.08 \pm 0.01 \mathrm{a}$ & $0.04 \pm 0.02 b$ \\
\hline $\mathrm{Cu}(\mathrm{c}$ & $16.0 \pm 0.96 \mathrm{a}$ & $17.4 \pm 0.87 \mathrm{a}$ \\
\hline $\mathrm{Zn}(\mathrm{c}$ & $32.5 \pm 1.37 \mathrm{a}$ & $16.7 \pm 1.31 b$ \\
\hline$\left.(+) L^{-1}\right)^{y}$ & $104 \pm 17.2 \mathrm{a}$ & $60.1 \pm 5.84 b$ \\
\hline $\operatorname{Mn}\left(\operatorname{cmol}(+) \mathrm{L}^{-1}\right)^{y}$ & $219 \pm 13.7 b$ & $277 \pm 12.7 \mathrm{a}$ \\
\hline
\end{tabular}

were recorded for the fresh material. All leaves of each plant were collected, scanned and the total leaf area was calculated using Digital Areas Determiner software, except for Poaceae species, in addition to Chamaecrista nictitans and Mimosa invisa. The five most expanded leaves were used for determination of the response to AMF in terms of leaf area expansion by the equation $100 \times$ (AMFA - NAMF)/AMFA, where AMFA represents the leaf area of the five most expanded leaves from each mycorrhizal plant, and NAMF corresponds to the area of the five most expanded leaves from each non-mycorrhizal plant. Roots and shoots were oven-dried at $65^{\circ} \mathrm{C}$, weighed and the root/shoot ratio was calculated. The dry weight of flowers was recorded separately. The relative growth rate (RGR) was determined according to Hunt (1982), using the equation $\mathrm{RGR}=\left(\ln \mathrm{W}_{\mathrm{t} 2}-\ln \mathrm{W}_{\mathrm{t} 1}\right) / \mathrm{t} 2-\mathrm{t} 1$, where $\mathrm{W}$ is the average of total plant dry mass and $\mathrm{t}$ is the time measured in days $(\mathrm{t} 1=3 \mathrm{~d}$ after plant emergence, and $\mathrm{t} 2=$ days elapsed after plant emergence until the end of experiment). The specific root length was the ratio between total root length and root dry mass. The concentrations of $\mathrm{P}, \mathrm{K}, \mathrm{Ca}$ and $\mathrm{Mg}$ in the shoots were quantified in nitric-perchloric digests, while $\mathrm{N}$ was determined in sulphuric acid digests (Silva 1999). Due to the small amount of biomass, it was not possible to analyse the nutrients in the shoots of plants grown in the low-fertility soil.

\section{Mycorrhizal infection intensity and plant biomass response to AMF}

Before drying roots, subsamples offine roots were collected from each plant and mycorrhizal root infection intensity was determined after clarifying $(10 \% \mathrm{KOH})$, acidifying $(1 \% \mathrm{HCl})$ and staining $(0.05 \%$ trypan blue) according to Brundrett et al. (1996). Then, the intersection method on gridded plates (McGonigle et al. 1990) was employed, considering the presence of fungal structures (coenocytic hyphae, arbuscules and vesicles) at $\times 100$ magnification. Plant biomass response to AMF was calculated by the equation $100 \times($ SBAM - SBNM $) / S B A M$, where SBAM represents the shoot dry mass of mycorrhizal plant, and SBNM corresponds to shoot dry mass of non-mycorrhizal plant (Plenchette et al. 1983).

\section{Data analyses}

Data were first tested for normality by Shapiro-Wilk's test and homoscedasticity by Levene's test. The chemical attributes of soils and the mycorrhizal effects within each level of soil fertility were compared by Student's $t$-test. Mycorrhizal infection intensity, plant biomass response and leaf area expansion were transformed to arcsine $(x / 100)$ before analysis. The averages of plant biomass response to AMF, mycorrhizal infection intensity and leaf area expansion considering all species in the low- and high-fertility soil were calculated and compared between each soil fertility level by Student's $t$-test. In all tests, $\mathrm{P}<$ 0.05 was considered significant.

\section{RESULTS}

The soil's chemical attributes were markedly higher in the high-fertility soil, except $\mathrm{Mg}$ and $\mathrm{Cu}$, which were similar, and $\mathrm{Al}, \mathrm{Fe}$ and $\mathrm{Zn}$, which were higher in the low-fertility soil (Table 2). Plant biomass response to AMF (Figure 1a) changed according to soil fertility. In the low-fertility soil, 17 out of 27 species exhibited $100 \%$ biomass response to AMF, given that the non-mycorrhizal plants died between 50-70 d after emergence. Amaranthus hybridus exhibited negative biomass response to AMF, while Leonotis nepetifolia did not survive in either treatment. The other species exhibited high biomass response to AMF, but below $100 \%$. The average plant biomass response to AMF in the low-fertility soil was $88 \%(n=26)$. On the other hand, in the high-fertility soil, plant biomass response to AMF varied according to plant species. Eight species had negative response, between $-44 \%$ and $-4 \%$; eight had positive response, between $2 \%$ and $19 \%$; nine had response between $21 \%$ to $50 \%$; while only L. nepetifolia and Leonurus sibiricus had response of above $60 \%$. The average plant biomass response to AMF in the highfertility soil was $13 \%(n=27)$, which significantly differed from the average response of the plants grown in the lowfertility soil (Figure 1a). 

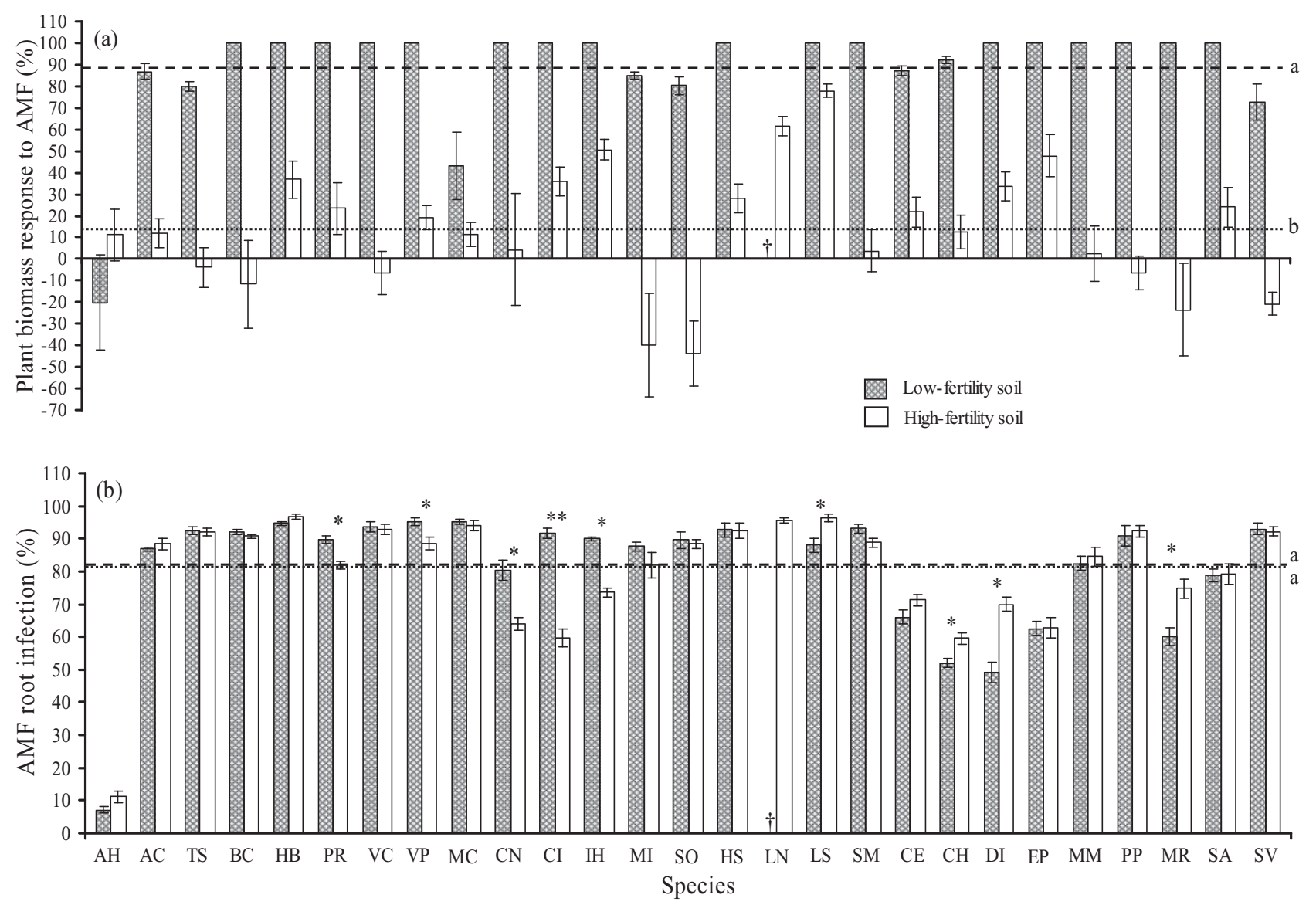

Figure 1. Difference in shoot biomass production between mycorrhizal and non-mycorrhizal plants expressed as a percentage of biomass for mycorrhizal plants (plant biomass response to AMF) (a) and AMF root infection intensity (b) of herbaceous and shrubby species of early stages of tropical succession grown in low- and high-fertility soils. Vertical bars indicate the standard error $(n=5)$. Dashed lines represent the average of plants response to AMF and mycorrhizal infection intensity considering all species in the low-fertility soil $(n=26)$; dotted lines represent the same in the high-fertility soil $(n=27)$. Means followed by the same letter do not differ from each other by Student's $t$-test at $\mathrm{P}<0.05$. $*$ Indicates significant differences in mycorrhizal infection intensity between soil fertilities within species by Student's $t$-test $(* \mathrm{P}<0.05 ; * * \mathrm{P}<0.01)$. $\dagger$ Represents death of the plants in the treatment. Species: $\mathrm{AH}=$ Amaranthus hybridus, $\mathrm{AC}=$ Asclepias curassavica, $\mathrm{BC}=$ Baccharis sp., $\mathrm{HB}=$ Hypochaeris brasiliensis, $\mathrm{PR}=$ Porophyllum ruderale, $\mathrm{VC}=$ Vernonia cognata, $\mathrm{VP}=$ Vernonia polyanthes, $\mathrm{TS}=$ Tecoma stans, $\mathrm{MC}=$ Momordica charantia, $\mathrm{CN}=$ Chamaecrista nictitans, $\mathrm{CI}=$ Crotalaria incana, $\mathrm{IH}=$ Indigofera hirsuta, $\mathrm{MI}=$ Mimosa invisa, $\mathrm{SO}=$ Senna obtusifolia, $\mathrm{HS}=$ Hyptis spicigera, $\mathrm{LN}=$ Leonotis nepetifolia, $\mathrm{LS}=$ Leonurus sibiricus, $\mathrm{SM}=$ Sidastrum micranthum, $\mathrm{CE}=$ Cenchrus echinatus, $\mathrm{CH}=$ Chloris elata, $\mathrm{DI}=$ Digitaria insularis, $\mathrm{EP}=$ Eragrostis pilosa, $\mathrm{MM}$ $=$ Melinis minutiflora, $\mathrm{MR}=$ Melinis repens, $\mathrm{PP}=$ Pennisetum purpureum, $\mathrm{SA}=$ Sorghum arundinaceum, $\mathrm{SV}=$ Solanum viarum.

Mycorrhizal root infection intensity was generally high (Figure 1b), except in A. hybridus, which was between $7 \%$ and $11 \%$. All the other species had more than $50 \%$ infection intensity, including more than $80 \%$ in 16 species, in both soils. Nine species differed in mycorrhizal infection for the two levels of soil fertility. Four species had higher AMF root infection in the low-fertility soil and five species exhibited higher values in the high-fertility soil. The average mycorrhizal infection across the two levels of soil fertility was about $80 \%$ (Figure 1b). Plants grown without AMF inoculation did not exhibit mycorrhizal infection in roots.

Non-mycorrhizal plants grown in the low-fertility soil had markedly lower shoot dry mass than mycorrhizal plants, except $A$. hybridus, which did not respond to the absence of AMF (Appendix 1). In the high-fertility soil, the majority of species did not respond to nonAMF condition; only nine species had reduced shoot biomass with non-mycorrhizal treatment. One species, Senna obtusifolia, displayed significant increase in shoot dry mass when non-mycorrhizal. Regarding root dry mass, except A. hybridus and Cenchrus echinatus, all species showed decreases in response to the non-AMF treatment in the low-fertility soil. On the other hand, most species did not respond to the absence of AMF in the high-fertility soil; five species responded negatively and three species responded positively to non-AMF. The root/shoot ratio changed with non-AMF in 11 species 
in both soils. In the low-fertility soil, $M$. invisa and $C$. echinatus exhibited an increase in the root/shoot ratio under the non-mycorrhizal condition. In the high-fertility soil, only $S$. obtusifolia had a decreased root/shoot ratio with non-mycorrhizal treatment, while eight species had an increased root/shoot ratio. The relative growth rate was reduced in the absence of AMF for most species grown in the low-fertility soil, while only A. hybridus and Momordica charantia exhibited no difference. In the highfertility soil, most species displayed no effects of non-AMF treatment on relative growth rate. Only seven species had a decreased relative growth rate, while S. obtusifolia and $M$. invisa had a higher relative growth rate when nonmycorrhizal.

Total root length was increased without AMF for the majority of species grown in the low-fertility soil, except C. echinatus, M. charantia and A. hybridus, which exhibited no difference (Appendix 1). In the high-fertility soil, most of the species exhibited no change with the non-AMF treatment, eight species displayed an increase, whereas Eragrostis pilosa and L. sibiricus exhibited a decrease with no AMF. The specific root length was increased in the absence of AMF for most species grown in the low-fertility soil, except $A$. hybridus, M. charantia and Tecoma stans, which exhibited no difference. In the high-fertility soil, 11 species had increased specific root length with nonmycorrhizal treatment, with no effect in the other species.

Only six species flowered in the low-fertility soil, four of which only flowered with mycorrhizal treatment (Figure 2). Senna obtusifolia and A. hybridus flowered in mycorrhizal and non-mycorrhizal conditions, but the first species produced fewer and later flowers under the nonmycorrhizal condition. In the high-fertility soil, 16 species flowered, three of which (Hypochaeris brasiliensis, Hyptis spicigera and M. charantia) only flowered when associated with AMF. Amaranthus hybridus, S. obtusifolia and E. pilosa flowered equally under mycorrhizal and non-mycorrhizal conditions, while 10 species had fewer flowers under the non-mycorrhizal condition. Among the 13 species that flowered in both conditions, eight flowered later under the non-mycorrhizal condition. Only Indigofera hirsuta and Sorghum arundinaceum flowered simultaneously under mycorrhizal and non-mycorrhizal conditions. However, A. hybridus, Digitaria insularis and E. pilosa flowered earlier without AMF (Figure 2). The non-mycorrhizal condition decreased the total flower dry weight (Appendix 1) of $S$. obtusifolia grown in the low-fertility soil, but there was no effect for $A$. hybridus. In the high-fertility soil, among the 13 species that flowered under mycorrhizal and nonmycorrhizal conditions, six had lower total flower dry weight with non-AMF treatment, whereas the remaining seven displayed no difference.

The non-AMF treatment decreased the total leaf area for the majority of species grown in both soils, except A. hybridus and M. charantia in the low-fertility soil, and 11 species in the high-fertility soil that exhibited no differences (Appendix 1). On average, leaf expansion was $58 \%(n=6)$ and $26 \%(n=17)$ reduced due to non-AMF condition in the low- and high-fertility soils, respectively, and these values are significantly different (Figure 3). In general, the nutritional status was negatively affected in the non-mycorrhizal plants. $\mathrm{N}$ decreased significantly in the shoots of 16 species, $\mathrm{P}$ in $24, \mathrm{~K}$ in 12 , Ca in 6 , and $\mathrm{Mg}$ in 10 species (Appendix 2). However, the nonAMF condition increased the nutrient concentration in some species, like Mg in M. invisa, E. pilosa and Melinis minutiflora, and $\mathrm{Ca}$ and $\mathrm{Mg}$ in I. hirsuta, Chloris elata and D. insularis.

\section{DISCUSSION}

\section{Mycorrhizal root infection}

The high values of mycorrhizal root infection in both levels of soil fertility suggest that the plant's habit can be more important in determining the intensity of AMF root infection than soil fertility. Previous studies have found high intensity of mycorrhizal root infection in herbaceous and shrubby species all over the tropical region (Kalinhoff et al. 2009, Lekberg et al. 2008, Muthukumar \& Prakash 2009, Zangaro et al. 2008, 2012b, 2014). Irrespective of soil fertility, herbaceous and shrubby species that predominate at the initial stages of tropical succession were highly receptive to AMF. Busby et al. (2011) and Wilson \& Hartnett (1998) have shown that temperate prairie and grassland herbaceous and shrubby species usually exhibit AMF root infection less than 50\% and the variation range of mycorrhizal infection between these species is high. We contend that such differences may be a result of the combination of plant habit and climatic characteristics typical of the tropics, like high light incidence, temperature and soil moisture (Zangaro et al. 2013, 2014). These characteristics improve plant photosynthetic capacity (Khurana \& Singh 2006, Lusk et al. 2008, Poorter \& Rozendaal 2008, Reich 1998) and the amount of photoassimilates exported to the roots (Lynch \& Ho 2005) for the maintenance of AMF. However, the mycorrhizal condition differentially affected plant growth, depending on the soil fertility level.

\section{Influence of AMF on plants grown in the low-fertility soil}

Plant growth was limited in the low-fertility soil, especially in the absence of AMF, resulting in a lack of plant growth and death in a few weeks. The few plant species that survived without AMF in this soil exhibited a severely limited shoot growth, but had high root/shoot ratio, 

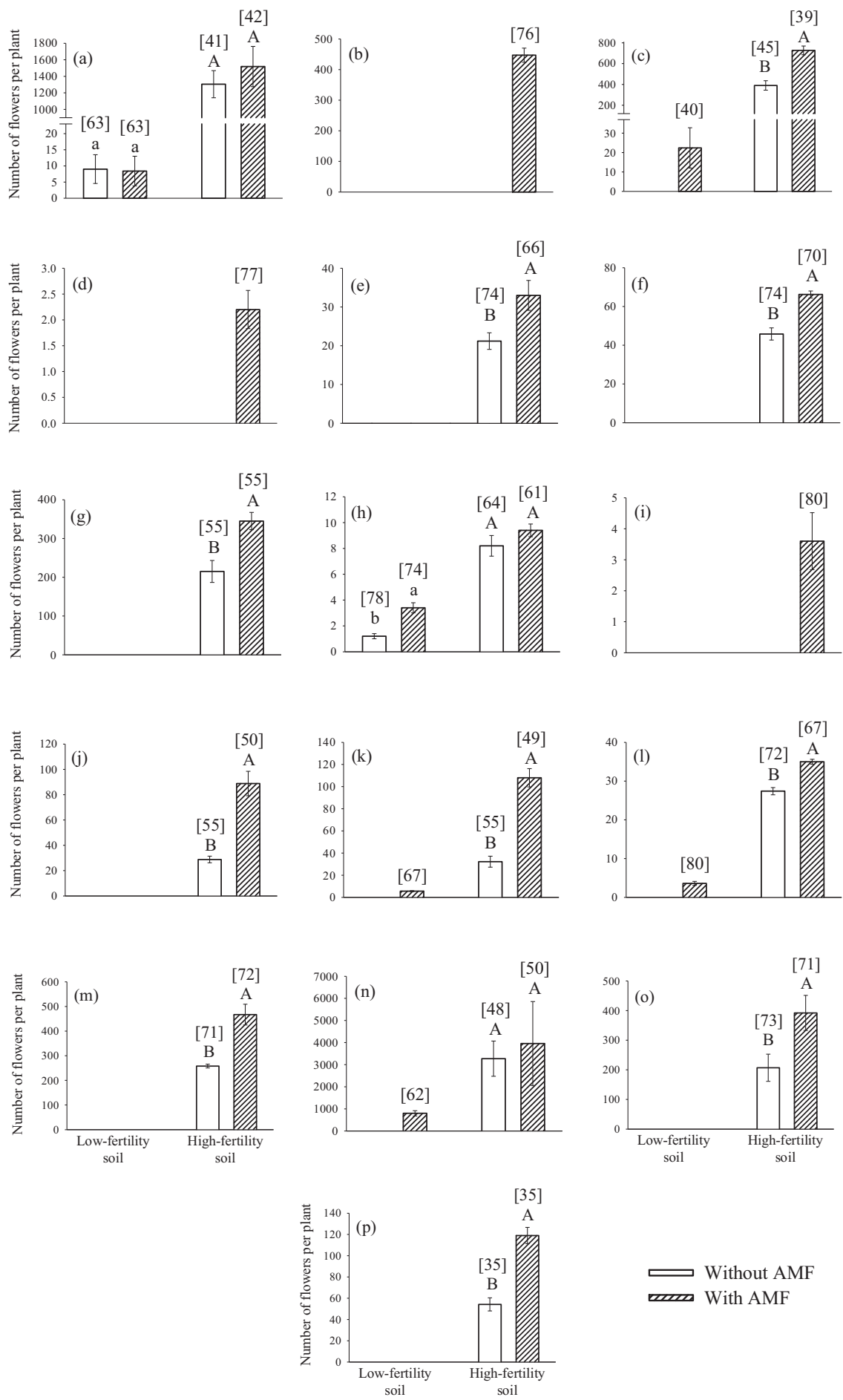

Figure 2. Number of flowers per plant and days elapsed for appearance of the first flower buds after plant emergence (number in brackets) of herbaceous and shrubby plant species of early stages of tropical succession grown in low- and high-fertility soils, with or without AMF. Vertical bars indicate the standard error $(n=5)$. Means followed by the same lowercase (low-fertility soil) or uppercase (high-fertility soil) letter do not differ by Student's $t$-test at $\mathrm{P}<0.05$. Species: Amaranthus hybridus (a), Hypochaeris brasiliensis (b), Porophyllum ruderale (c), Momordica charantia (d), Chamaecrista nictitans (e), Crotalaria incana (f), Indigofera hirsuta (g), Senna obtusifolia (h), Hyptis spicigera (i), Leonotis nepetifolia (j), Leonurus sibiricus (k), Cenchrus echinatus (l), Digitaria insularis (m), Eragrostis pilosa (n), Melinis repens (o), Sorghum arundinaceum (p). 


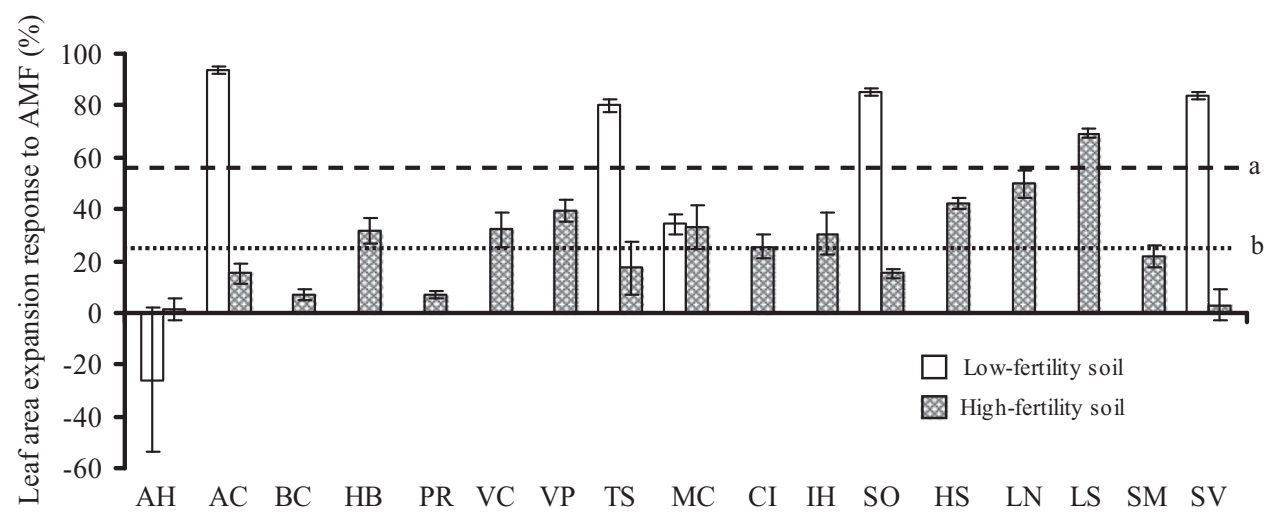

Figure 3. Difference in leaf area expansion between mycorrhizal and non-mycorrhizal plants expressed as a percentage of leaf area expansion for mycorrhizal plants (leaf area expansion response to AMF) of herbaceous and shrubby species of early stages of tropical succession grown in lowand high-fertility soils, without or with AMF. This variable could not be calculated for Chamaecrista nictitans, Mimosa invisa and the plant species of Poaceae. Vertical bars indicate the standard error $(n=5)$. Dashed lines represent the average of leaf area expansion considering all species in the low-fertility soil $(n=6)$; dotted lines represent the same in the high-fertility soil $(n=17)$. Means followed by the same letter do not differ from each other by Student's $t$-test at $\mathrm{P}<0.05$. Plant species abbreviations as in Figure 1 .

and fine roots with high specific length. These changes in root morphological traits represent an investment of photoassimilates in roots, aimed at better soil exploration for nutrients (Comas \& Eissenstat 2004, Zangaro et al. 2007). Herbaceous and shrubby species typically have a short lifespan (Lorenzi 2000) and high metabolic and growth rates (Reich 1998). To meet their high nutritional demands and reach the reproductive stage before the end of their short lifespan, these species developed a fine-root system morphologically adapted for a high potential for acquisition of water and nutrients, exhibiting high total and specific length, low diameter and high incidence of absorbing hairs (Zangaro et al. 2008, 2012a, 2014). In this study, such root morphological traits were not enough for these plants to meet all the nutritional requirements for shoot growth in the low-fertility soil. Nevertheless, except $L$. nepetifolia, all plants in symbiosis with AMF survived, and exhibited moderate growth due to the hyphal net associated with the fine-root system (Smith et al. 2011). The increase in nutrient uptake via AMF enabled plant survival and growth in the lowfertility soil. Under this condition, most of the herbaceous and shrubby species were highly dependent on AMF for survival and growth. Amaranthus hybridus was the only species in which we observed a negative biomass response to AMF in the low-fertility soil. This may be due to the low mycorrhizal infection intensity exhibited in its roots. When mycorrhizal, plants may have the P uptake by root epidermis partially or totally inhibited, and AMF become the main way by which plants obtain P from soil (Li et al. 2008, Smith et al. 2009). Therefore, A. hybridus plants, that had low mycorrhizal root infection, exhibited growth depression in the low-fertility soil because they may have been unable to absorb $\mathrm{P}$ via root epidermis and AMF in suitable amounts.
Considering that these herbaceous and shrubby species typically predominate in the early tropical succession in low-fertility and degraded soils (Zangaro et al. 2012a, $b, 2013)$, and that the cost of $C$ for the maintenance of the hyphal net is at least two orders of magnitude smaller than producing the same length of fine roots (Smith \& Read 2008), the investment in C for the maintenance of high intensity of AMF infection can be understood as a highly attractive option for these species to more efficiently acquire nutrients from low-fertility soils. Moreover, mycorrhizal root infection intensity is correlated with the number of spores in soil (Zangaro et al. 2012b), which are the main AMF propagules (Smith \& Read 2008). As seen, the herbaceous and shrubby species at the early tropical succession are efficient multipliers of AMF, enriching the soil with propagules, which may help: (1) their own growth; (2) the establishment of their offspring; (3) the further establishment of woody pioneer and early-secondary species in the succession, which are highly responsive to AMF and structure the initial phases of the tropical secondary forest (Zangaro et al. 2000, 2007, 2012b). The crucial importance of AMF for survival and growth of herbaceous and shrubby species that occupy the same early-successional stages in the tropics places them as obligate partners to help plants to colonize sites with low-fertility or degraded soils, commonly found in tropical environments. In the absence of AMF, the early stages of succession may not occur, negatively affecting the subsequent successional stages.

Among the few species that flowered in the low-fertility soil, most of them did so only in the presence of AMF, which was attributed to a better nutritional status of mycorrhizal plants. For species with a short lifespan, flowering is quick and the investment in terms of energy in the reproductive organs is high (Newell \& Tramer 
1978). Thus, species grown in low-fertility soil, besides obtaining benefits from AMF, may also have a stimulated photosynthetic rate (Yolanda et al. 2012) that allows better allocation of photoassimilates and nutrients for producing flowers (Stanley et al. 1993).

\section{Influence of AMF on plants grown in high-fertility soil}

In the fertile soil, the high intensity of mycorrhizal root infection had only slight effects on plant growth, shoot and root biomass, total and specific root length, and root/shoot ratio. Only a few species had high response to AMF, whereas the response was low or negative for the majority of plant species, resulting in low average biomass response of the plants in the high-fertility soil, as previously observed by Peng et al. (1993), Perner et al. (2007) and Veiga et al. (2011). The slight accumulation of plant biomass was probably a consequence of a $\mathrm{C}$ sink under high AMF root infection intensity (Lynch \& Ho 2005, Ryan et al. 2005). In this fertile soil, most of the plant species that had a low biomass increase under the mycorrhizal condition also had an increase in the total leaf area and leaf expansion, providing a probable increase in photosynthetic potential compared with nonmycorrhizal plants. Thus, the increase in leaf area and photosynthetic rate can be a plant's response to the increased demand for $\mathrm{C}$ due to high intensity of AMF root infection, as observed for Trifolium repens (Wright et al. 1998). Despite the low plant biomass response to AMF in the high-fertility soil, there was an increase in nutrient concentrations in the shoots, which might have compensated the $\mathrm{C}$ sink.

The better nutritional status of mycorrhizal plants may result in further benefits beside the increase in biomass, like resistance to pathogens (Wehner et al. 2010) and drought (Augé 2001). However, it is possible that the improvement in the nutritional status of herbaceous and shrubby species, at the expense of dry matter production, may be related to a better performance in flowering. In the high-fertility soil, some species flowered only when associated with AMF and the majority of plant species had earlier and more abundant flowering with AMF. Moreover, in some species, the total dry mass of flowers was also increased when associated with AMF. As a result, AMF may influence at least three features of the sexual reproduction of herbaceous and shrubby tropical species in fertile soils: (1) earlier flowering; (2) higher allocation of biomass to flowers; (3) increase in the number of flowers per plant. Previous studies have shown a positive influence of AMF on the flowering of fast-growing herbaceous species (Gange \& Smith 2005, Lu \& Koide 1994, Perner et al. 2007, Stanley et al. 1993), which has been attributed mainly to the increase in $\mathrm{P}$ and K uptake (Koide \& Dickie 2002, Perner et al. 2007).
Thus, AMF modulate the pattern of $\mathrm{C}$ use in herbaceous and shrubby tropical species. Lower $\mathrm{C}$ accumulation in shoots makes more $\mathrm{C}$ available to AMF in roots, improving the plant's nutritional status, which results in earlier and more abundant flowering.

Short-lived plants are usually highly prolific, which increases their competitiveness, especially in already occupied sites (Aarssen \& Taylor 1992, Norris 2007). In the fertile soil of this study, the herbaceous and shrubby species survived, grew and flowered even without AMF. However, when associated with AMF, the plants accumulated more nutrients in a shorter time, so that they could bloom earlier in their life cycle (Perner et al. 2007), and also increase flower production, both of which can be advantageous in competition at the beginning of tropical succession. Furthermore, AMF can also improve reproductive capacity of plants because they make some floral attributes more favourable to pollination. For example, tomato plants associated with AMF had flowers with more pollen, which had a higher formation rate of the pollen tube (Poulton et al. 2002); and in two Asteraceae herbaceous species, AMF led to an increase in the size of inflorescence and sugar content in nectar, which stimulated a higher visitation of flowers by pollinators (Gange \& Smith 2005). The increased flowering in mycorrhizal plants can also improve the efficiency of pollination as well as seed production (Gange \& Smith 2005), whereas the seeds produced by plants colonized by AMF commonly have a higher nutrient content (Gange \& Smith 2005, Stanley et al. 1993) and generate more vigorous, competitive and reproductive offspring (Heppell et al. 1998). We contend that the mobilization of $\mathrm{C}$ to maintain high intensity of AMF root infection, even resulting in low accumulation of shoot biomass, which is equilibrated by leaf expansion, can be an advantage for plants because it improves their nutritional status, fecundity and seed quality, which results in offspring that is more effective in colonizing the environment. Moreover, the lower production of shoot biomass by plants with $\mathrm{AMF}$, in some cases, may not be a competitive disadvantage, because the herbaceous and shrubby heliophilous species, with low height and short lifespan, have a tendency to compete more for space among them than for light.

In summary, herbaceous and shrubby heliophilous species make a functional group in tropical succession that has high association with AMF. However, the influence of AMF root infection intensity in these species depends on soil fertility. In low-fertility soils, the mycorrhizal symbiosis is crucial for plant survival, growth and reproduction. On the other hand, in fertile soils the high AMF root infection intensities, despite not resulting in high plant response, are advantageous because they improve the nutritional status that results in early flowering and higher production of flowers. Thus, 
assessing the importance of mycorrhizal symbiosis for this plant functional group based only on responses in terms of biomass accumulation may not be appropriate and may lead to erroneous conclusions in the ecological sense.

\section{ACKNOWLEDGEMENTS}

The authors would like to thank Osmar Rodrigues Brito for assistance in nutrient determination. Thanks to Edson Mendes Francisco for assistance during the seed collecting and Valdecir A. Castilho for soil sampling. Waldemar Zangaro and Marco A. Nogueira are CNPq scholars.

\section{LITERATURE CITED}

AARSSEN, L. W. \& TAYLOR, D. R. 1992. Fecundity allocation in herbaceous plants. Oikos 65:225-232.

AUGÉ, R. M. 2001. Water relations, drought and vesicular-arbuscular mycorrhizal symbiosis. Mycorrhiza 11:3-42.

BRUNDRETT, M., BEEGHER, N., DELL, B., GROOVE, T. \& MALAJCZUK, N. 1996. Working with mycorrhizas in forestry and agriculture. ACIAR Monograph, Canberra. 374 pp.

BUSBY, R. R., GEBHART, D. L., STROMBERGER, M. E., MEIMAN, P. J. \& PASCHKE, M. W. 2011. Early seral plant species' interactions with an arbuscular mycorrhizal fungi community are highly variable. Applied Soil Ecology 48:257-262.

COMAS, L. H. \& EISSENSTAT, D. M. 2004. Linking fine root traits to maximum potential growth rate among 11 mature temperate tree species. Functional Ecology 18:388-397.

DEFILIPPO, B. V. \& RIBEIRO, A. C. 1997. Análise química do solometodologia. Universidade Federal de Viçosa, Viçosa. 26 pp.

FAO. 1994. Soil map of the world. FAO-UNESCO, Rome. 140 pp.

GANGE, A. C. \& SMITH, A. K. 2005. Arbuscular mycorrhizal fungi influence visitation rates of pollinating insects. Ecological Entomology 30:600-606.

GRMAN, E. 2012. Plant species differ in their ability to reduce allocation to non-beneficial arbuscular mycorrhizal fungi. Ecology 93:711718.

GUARIgUATA, M. R. \& OSTERTAG, R. 2001. Neotropical secondary forest succession: changes in structural and functional characteristics. Forest Ecology and Management 148:185-206.

HEPPELL, K. B., SHUMWAY, D. L. \& KOIDE, R. T. 1998. The effect of mycorrhizal infection of Abutilon theophrasti on competitiveness of offspring. Functional Ecology 12:171-175.

HUNT, R. 1982. Plant growth curves: the functional approach to plant growth analysis. University Park Press, Baltimore. 248 pp.

JOHNSON, N. C. 2010. Resource stoichiometry elucidates structure and function of arbuscular mycorrhizas across scales. New Phytologist 185:631-647.

JOHNSON, N. C., GRAHAM, J. H. \& SMITH, F. A. 1997. Functioning of mycorrhizal associations along the mutualismparasitism continuum. New Phytologist 135:575-585.

KALINHOFF, C., CÁCERES, A. \& LUGO, L. 2009. Mudanças na biomassa de raízes e micorrizas arbusculares em cultivos itinerantes do Amazonas Venezolano. Interciencia 34:571-576.
KEENEY, D. R. \& NELSON, D. W. 1982. Nitrogen inorganic forms. Pp. 643-698 in Page, A. L., Miller, R. H. \& Keeney, D.R. (eds.). Methods of soil analysis: chemical and microbiological properties. American Society of Agronomy, Madison.

KHURANA, E. \& SINGH, J. S. 2006. Impact of life-history traits on response of seedlings of five tree species of tropical dry forest to shade. Journal of Tropical Ecology 22:653-661.

KIERS, E. T., DUHAMEL, M., BEESETTY, Y., MENSAH, J. A., FRANKEN, O., VERBRUGGEN, E., FELLBAUM, C. R., KOWALCHUK, G. A., HART, M. M., BAGO, A., PALMER, T. M., WEST, S. A., VANDENKOORNHUYSE, P., JANSA, J. \& BÜCKING, H. 2011. Reciprocal rewards stabilize cooperation in the mycorrhizal symbiosis. Science 333:880-882.

KLIRONOMOS, J. N. 2003. Variation in plant response to native and exotic arbuscular mycorrhizal fungi. Ecology 84:2292-2301.

KOIDE, R. T. \& DICKIE, I. A. 2002. Effects of mycorrhizal fungi on plant populations. Plant and Soil 244:307-317.

KRANZ, W. M., FONSECA JUNIOR, N. S., PASSINI, T. \& MARTINS, N. M. B. 2009. Ocorrência e distribuição de plantas daninhas no Paraná. Iapar, Londrina. 283 pp.

LEITÃOFILHO, H.F., ARANHA, C.\&BACCHI, O. 1972. Plantasinvasoras de culturas no Estado de São Paulo. Hucitec, São Paulo. 291 pp.

LEKBERG, Y., KOIDE, R. T. \& TWOMLOW, S. J. 2008. Effect of agricultural management practices on arbuscular mycorrhizal fungal abundance in low-input cropping systems of southern Africa: a case study from Zimbabwe. Biology and Fertility of Soils 44:917923.

LI, H., SMITH, F. A., DICKSON, S., HOLLOWAY, R. E. \& SMITH, S. E. 2008. Plant growth depressions in arbuscular mycorrhizal symbioses: not just caused by carbon drain? New Phytologist 178:852-862.

LORENZI, H. 2000. Plantas daninhas do Brasil: terrestres, aquáticas, parasitas e tóxicas. Instituto Plantarum, Nova Odessa. 608 pp.

LU, X. \& KOIDE, R. T. 1994. The effects of mycorrhizal infection on components of plant growth and reproduction. New Phytologist 128:211-218.

LUSK, C. H., REICH, P. B., MONTGOMERY, R. A., ACKERLY, D. D. \& CAVENDER-BARES, J. 2008. Why are evergreen leaves so contrary about shade? Trends in Ecology and Evolution 23:299-303.

LYNCH, J. P. \& HO, M. D. 2005. Rhizoeconomics: carbon costs of phosphorus acquisition. Plant and Soil 269:45-56.

MANGAN, S. A., EOM, A., ADLER, G. H., YAVITT, J. B. \& HERRE, E. A. 2004. Diversity of arbuscular mycorrhizal fungi across a fragmented forest in Panama: insular spores communities differ from mainland communities. Oecologia 141:687-700.

McGONIGLE, T. P., EVANS, D. G. \& MILLER, M. H. 1990. Effect of degree of soil disturbance on mycorrhizal colonization and phosphorus absorption by maize in growth chamber and field experiments. New Phytologist 116:629-636.

MUTHUKUMAR, T. \& PRAKASH, S. 2009. Arbuscular mycorrhizal morphology in crops and associated weeds in tropical agroecosystems. Mycoscience 50:233-239.

NEWELL, S. J. \& TRAMER, E. J. 1978. Reproductive strategies in herbaceous plant communities during succession. Ecology 59:228234. 
NORRIS, R. F. 2007. Weed fecundity: current status and future needs. Crop Protection 26:182-188.

PAVAN, M. A., BLOCH, M. F., ZEMPULSKI, H. C., MIYAZAWA, M. \& ZOCOLER, D.C. 1992. Manual de análise química de solo e controle de qualidade. IAPAR, Londrina. $40 \mathrm{pp}$.

PENG, S., EISSENSTAT, D. M., GRAHAM, J. H., WILLIAMS, K. \& HODGE, N. C. 1993. Growth depression in mycorrhizal citrus at high-phosphorus supply. Plant Physiology 101:1063-1071.

PERNER, H., SCHWARTZ, D., BRUNS, C., MÄDER, P. \& GEORGE, E. 2007. Effect of arbuscular mycorrhizal colonization and two levels of compost supply on nutrient uptake and flowering of pelargonium plants. Mycorrhiza 17:469-474.

PLENCHETTE, C., FORTIN, J. A. \& FURLAN, V. 1983. Growth response of several plants species to mycorrhiza in a soil of moderate $\mathrm{P}$ fertility. I. Mycorrhizal dependency under field conditions. Plant and Soil 70:191-209.

POORTER, L. \& ROZENDAAL, D. M. A. 2008. Leaf size and leaf display of thirty-eight tropical tree species. Oecologia 158:35-46.

POULTON, J. L., BRYLA, D., KOIDE, R. T. \& STEPHENSON, A. G. 2002. Mycorrhizal infection and high soil phosphorus improve vegetative growth and the female and male functions in tomato. New Phytologist 154:255-264.

REICH, P. B. 1998. Variation among plant species in leaf turnover rates and associated traits: implications for growth at all life stages. Pp. 467-487 in Cambers, H., Porter, H. \& van Vuuren, M. M. I. (eds.). Physiological mechanisms and ecological consequences. Backhuys Publishing, Leiden.

RYAN, M.H., VANHERWAARDEN, A.F., ANGUS, J.F. \& KIRKEGAARD, J. A. 2005. Reduced growth of autumn-sown wheat in a low-P is associated with high colonization by arbuscular mycorrhizal fungi. Plant and Soil 270:275-286.

SILVA, F. C. 1999. Manual de análises químicas de solos, plantas e fertilizantes. Embrapa, Brasilia. 370 pp.

SMITH, F. A., GRACE, E. J. \& SMITH, S. E. 2009. More than a carbon economy: nutrient trade and ecological sustainability in facultative arbuscular mycorrhizal symbioses. New Phytologist 182:347-358.

SMITH, S. E. \& READ, D. J. 2008. Mycorrhizal symbiosis. Academic Press, London. 797 pp.

SMITH, S. E., JAKOBSEN, I., GRØLUND, M. \& SMITH, F. A. 2011. Roles of arbuscular mycorrhizas in plant phosphorus nutrition: interactions between pathways of phosphorus uptake in arbuscular mycorrhizal roots have important implications for understanding and manipulating plant phosphorus acquisition. Plant Physiology 156:1050-1057.

STANLEY, M. R., KOIDE, R. T. \& SHUMWAY, D. L. 1993. Mycorrhizal symbiosisincreases growth, reproduction and recruitment of Abutilon theophrasti Medic. in the field. Oecologia 94:30-35.

STÜRMER, S. L. \& SIQUEIRA, J. O. 2011. Species richness and spore abundance of arbuscular mycorrhizal fungi across distinct land uses in Western Brazilian Amazon. Mycorrhiza 21:255-267.

TENNANT, D. 1975. A test of modified line intersect method of estimating root length. Journal of Ecology 63:995-1001.
VEIGA, R. S. L., JANSA, J., FROSSARD, E. \& VAN DER HEIJDEN, M. G. A. 2011. Can arbuscular mycorrhizal fungi reduce the growth of agricultural weeds? PloS ONE 6:e27825. doi: 10.1371/journal.pone.0027825.

WEHNER, J., ANTUNES, P. M., POWELL, J. R., MAZUKATOW, J. \& RILLING, M. C. 2010. Plant pathogen protection by arbuscular mycorrhizas: a role for fungal diversity? Pedobiologia 53:197201.

WILSON, G. W. T. \& HARTNETT, D. C. 1998. Interspecific variation in plant responses to mycorrhizal colonization in tallgrass prairie. American Journal of Botany 85:1732-1738.

WRIGHT, D. P., SCHOLES, J. D. \& READ, D. J. 1998. Effects of VA mycorrhizal colonization on photosynthesis and biomass production of Trifolium repens L. Plant Cell and Environment 21:209-216.

YOLANDA, N. G., CERRATO, R. F. \& SANTAMARÍA, R. F. 2012. Glomus intraradices attenuates the negative effect of low Pi supply on photosynthesis and growth of papaya Maradol plants. Journal of Botany 2012:ID129591. doi: 10.1155/2012/129591

ZANGARO, W., BONONI, V. L. R. \& TRUFEM, S. B. 2000. Mycorrhizal dependency, inoculum potential and habitat preference of native woody species in South Brazil. Journal of Tropical Ecology 16:603622.

ZANGARO, W., NISHIDATE, F. R., VANDRESEN, J., ANDRADE, G. \& NOGUEIRA, M. A. 2007. Root mycorrhizal colonization and plant responsiveness are related to root plasticity, soil fertility and successional status of native woody species in southern Brazil. Journal of Tropical Ecology 23:53-62.

ZANGARO, W., ASSIS, R. L., ROSTIROLA, L. V., SOUZA, P. B., GONÇALVES, M. C., ANDRADE, G. \& NOGUEIRA, M. A. 2008. Changes in arbuscular mycorrhizal associations and fine root traits in sites under different plant successional phases in southern Brazil. Mycorrhiza 19:37-45.

ZANGARO, W., ALVES, R. A., LESCANO, L. E., ANSANELO, A. P. \& NOGUEIRA, M. A. 2012a. Investment in fine roots and arbuscular mycorrhizal fungi decrease during succession in three Brazilian ecosystems. Biotropica 44:141-150.

ZANGARO, W., ANSANELO, A. P., LESCANO, L. E. A. M., ALVES, R. A., RONDINA, A. B. L. \& NOGUEIRA, M. A. 2012b. Infection intensity, spore density and inoculum potential of arbuscular mycorrhizal fungi decrease during secondary succession in tropical Brazilian ecosystems. Journal of Tropical Ecology 28:453-462.

ZANGARO, W., ROSTIROLA, L. V., SOUZA, P. B., ALVES, R. A., LESCANO, L. E. A. M., RONDINA, A. B. L., NOGUEIRA, M. A. \& CARRENHO, R. 2013. Root colonization and spore abundance of arbuscular mycorrhizal fungi in distinct successional stages from an Atlantic rainforest biome in southern Brazil. Mycorrhiza 23:221233.

ZANGARO, W., ALVES, R. A., SOUZA, P. B., ROSTIROLA, L. V., LESCANO, L. E. A. M., RONDINA, A. B. L. \& NOGUEIRA, M. A. 2014. Succession and environmental variation influence soil exploration potential by fine roots and mycorrhizal fungi in an Atlantic ecosystem in southern Brazil. Journal of Tropical Ecology 30:237-248. 
Appendix 1. Mean ( \pm SD) for shoot dry mass (SDM), root dry mass (RDM), root/shoot ratio (R/S), relative growth rate (RGR), total root length (TRL), specific root length (SRL), total flower dry weight (TFDW) and total leaf area (TLA) of herbaceous and shrubby species of early stages of tropical succession grown in soils with low (L) and high (H) fertility, without ( $-\mathrm{M})$ or with (+M) AMF. Means followed by the same lowercase (for the low-fertility soil) or uppercase (for the high-fertility soil) letter do not differ by Student's $t$-test at $\mathrm{P}<0.05$ ( $n=5$ ). \#, $\S$ and $\dagger$ indicate death of the plants in the treatment after 50, 60 and 70 d of emergence, respectively.

\begin{tabular}{|c|c|c|c|c|c|c|c|c|c|}
\hline Soil & AMF & $\begin{array}{c}\text { SDM } \\
(\mathrm{g})\end{array}$ & $\begin{array}{c}\text { RDM } \\
(\mathrm{g})\end{array}$ & $\begin{array}{c}\mathrm{R} / \mathrm{S} \\
\left(\mathrm{g} \mathrm{g}^{-1}\right)\end{array}$ & $\begin{array}{c}\text { RGR } \\
\left(\mathrm{mg} \mathrm{g}^{-1} \mathrm{~d}^{-1}\right)\end{array}$ & $\begin{array}{c}\text { TRL } \\
\text { (m per plant) }\end{array}$ & $\begin{array}{c}\mathrm{SRL} \\
\left(\mathrm{m} \mathrm{g}^{-1}\right)\end{array}$ & $\begin{array}{c}\text { TFDW } \\
\text { (g per plant) }\end{array}$ & $\begin{array}{c}\text { TLA } \\
\left(\mathrm{cm}^{2} \text { per plant }\right)\end{array}$ \\
\hline \multicolumn{10}{|c|}{ Amarantus hybridus } \\
\hline \multirow[t]{2}{*}{$\mathrm{L}$} & $-\mathrm{M}$ & $0.01 \pm 0.01 \mathrm{a}$ & $0.01 \pm 0.01 \mathrm{a}$ & $1.02 \pm 0.52 \mathrm{a}$ & $31.1 \pm 5.57 \mathrm{a}$ & $4.33 \pm 3.10 \mathrm{a}$ & $426 \pm 66.0 \mathrm{a}$ & $0.01 \pm 0.01 \mathrm{a}$ & $0.74 \pm 0.26 \mathrm{a}$ \\
\hline & $+\mathrm{M}$ & $0.01 \pm 0.01 \mathrm{a}$ & $0.01 \pm 0.01 \mathrm{a}$ & $0.53 \pm 0.31 \mathrm{a}$ & $25.1 \pm 3.57 \mathrm{a}$ & $2.20 \pm 1.45 \mathrm{a}$ & $741 \pm 494 a$ & $0.01 \pm 0.01 \mathrm{a}$ & $0.49 \pm 0.28 \mathrm{a}$ \\
\hline \multirow[t]{2}{*}{$\mathrm{H}$} & $-\mathrm{M}$ & $1.31 \pm 0.44 \mathrm{~A}$ & $0.29 \pm 0.07 \mathrm{~A}$ & $0.20 \pm 0.03 \mathrm{~A}$ & $76.4 \pm 3.31 \mathrm{~A}$ & $242 \pm 44.9 \mathrm{~A}$ & $955 \pm 249 \mathrm{~A}$ & $0.38 \pm 0.12 \mathrm{~A}$ & $79.0 \pm 27.5 \mathrm{~A}$ \\
\hline & $+\mathrm{M}$ & $1.48 \pm 0.17 \mathrm{~A}$ & $0.38 \pm 0.06 \mathrm{~A}$ & $0.26 \pm 0.06 \mathrm{~A}$ & $77.6 \pm 0.87 \mathrm{~A}$ & $284 \pm 54.3 \mathrm{~A}$ & $740 \pm 102 \mathrm{~A}$ & $0.47 \pm 0.15 \mathrm{~A}$ & $94.7 \pm 19.4 \mathrm{~A}$ \\
\hline \multicolumn{10}{|c|}{ Asclepias curassavica } \\
\hline \multirow[t]{2}{*}{$\mathrm{L}$} & $-\mathrm{M}$ & $0.01 \pm 0.01 \mathrm{~b}$ & $0.01 \pm 0.01 b$ & $0.89 \pm 0.40$ & $16.8 \pm 1.51 \mathrm{~b}$ & $3.25 \pm 1.03 \mathrm{~b}$ & $410 \pm 243 a$ & - & $0.27 \pm 0.18 b$ \\
\hline & $+\mathrm{M}$ & $0.09 \pm 0.02 \mathrm{a}$ & $0.08 \pm 0.02 \mathrm{a}$ & $0.85 \pm 0.04 \mathrm{a}$ & $42.2 \pm 3.75 \mathrm{a}$ & $10.1 \pm 2.16 \mathrm{a}$ & $130 \pm 23.0 b$ & - & $14.4 \pm 5.19 \mathrm{a}$ \\
\hline \multirow[t]{2}{*}{$\mathrm{H}$} & $-\mathrm{M}$ & $1.38 \pm 0.20 \mathrm{~A}$ & $1.29 \pm 0.19 \mathrm{~A}$ & $0.94 \pm 0.13 \mathrm{~A}$ & $68.3 \pm 2.92 \mathrm{~B}$ & $109 \pm 31.6 \mathrm{~A}$ & $84.1 \pm 21.0 \mathrm{~A}$ & - & $111 \pm 12.9 \mathrm{~B}$ \\
\hline & $+\mathrm{M}$ & $1.58 \pm 0.17 \mathrm{~A}$ & $1.21 \pm 0.19 \mathrm{~A}$ & $0.76 \pm 0.14 \mathrm{~A}$ & $75.8 \pm 5.52 \mathrm{~A}$ & $72.5 \pm 8.43 \mathrm{~B}$ & $60.2 \pm 4.91 \mathrm{~B}$ & - & $145 \pm 24.2 \mathrm{~A}$ \\
\hline \multicolumn{10}{|c|}{ Baccharis sp. } \\
\hline \multirow[t]{2}{*}{$\mathrm{L}$} & $-\mathrm{M}$ & $\S$ & $\S$ & $\S$ & $\S$ & $\S$ & $\S$ & $\S$ & $\S$ \\
\hline & $+\mathrm{M}$ & $0.14 \pm 0.11$ & $0.10 \pm 0.11$ & $0.68 \pm 0.12$ & $54.9 \pm 7.66$ & $28.5 \pm 35.2$ & $257 \pm 111$ & - & $19.9 \pm 12.9$ \\
\hline \multirow[t]{2}{*}{$\mathrm{H}$} & $-\mathrm{M}$ & $1.39 \pm 0.22 \mathrm{~A}$ & $0.87 \pm 0.29 \mathrm{~A}$ & $0.62 \pm 0.17 \mathrm{~A}$ & $80.5 \pm 1.94 \mathrm{~A}$ & $205 \pm 89.6 \mathrm{~A}$ & $229 \pm 43.4 \mathrm{~A}$ & - & $136 \pm 15.3 \mathrm{~A}$ \\
\hline & $+\mathrm{M}$ & $1.41 \pm 0.55 \mathrm{~A}$ & $0.61 \pm 0.11 \mathrm{~A}$ & $0.31 \pm 0.07 \mathrm{~B}$ & $77.7 \pm 4.96 \mathrm{~A}$ & $51.8 \pm 20.4 \mathrm{~B}$ & $127 \pm 30.2 \mathrm{~B}$ & - & $151 \pm 56.1 \mathrm{~A}$ \\
\hline \multicolumn{10}{|c|}{ Hypochaeris brasiliensis } \\
\hline \multirow[t]{2}{*}{$\mathrm{L}$} & $-\mathrm{M}$ & $\S$ & $\S$ & $\S$ & $\S$ & $\S$ & $\S$ & $\S$ & $\S$ \\
\hline & $+\mathrm{M}$ & $0.03 \pm 0.02$ & $0.03 \pm 0.02$ & $1.04 \pm 0.46$ & $42.0 \pm 7.76$ & $5.10 \pm 2.04$ & $186 \pm 65.2$ & - & $8.96 \pm 8.12$ \\
\hline \multirow[t]{2}{*}{$\mathrm{H}$} & $-\mathrm{M}$ & $0.49 \pm 0.10 \mathrm{~B}$ & $1.88 \pm 0.15 \mathrm{~A}$ & $3.89 \pm 0.58 \mathrm{~A}$ & $81.2 \pm 0.82 \mathrm{~A}$ & $233 \pm 95.1 \mathrm{~A}$ & $125 \pm 51.9 \mathrm{~A}$ & - & $119 \pm 38.1 \mathrm{~B}$ \\
\hline & $+\mathrm{M}$ & $0.85 \pm 0.30 \mathrm{~A}$ & $1.29 \pm 0.21 \mathrm{~B}$ & $1.61 \pm 0.64 \mathrm{~B}$ & $79.8 \pm 1.41 \mathrm{~A}$ & $130 \pm 41.2 \mathrm{~A}$ & $104 \pm 24.0 \mathrm{~A}$ & $0.82 \pm 0.11$ & $193 \pm 56.3 \mathrm{~A}$ \\
\hline \multicolumn{10}{|c|}{ Porophyllum ruderale } \\
\hline \multirow[t]{2}{*}{$\mathrm{L}$} & $-\mathrm{M}$ & $\dagger$ & $\dagger$ & $\dagger$ & $\dagger$ & $\dagger$ & $\dagger$ & $\dagger$ & $\dagger$ \\
\hline & $+\mathrm{M}$ & $0.10 \pm 0.06$ & $0.04 \pm 0.03$ & $0.42 \pm 0.16$ & $51.4 \pm 5.41$ & $9.57 \pm 6.10$ & $228 \pm 46.5$ & $0.02 \pm 0.01$ & $9.73 \pm 6.23$ \\
\hline \multirow[t]{2}{*}{$\mathrm{H}$} & $-\mathrm{M}$ & $1.36 \pm 0.43 \mathrm{~A}$ & $0.43 \pm 0.17 \mathrm{~A}$ & $0.31 \pm 0.05 \mathrm{~A}$ & $75.5 \pm 4.76 \mathrm{~A}$ & $56.4 \pm 24.3 \mathrm{~A}$ & $130 \pm 18.6 \mathrm{~A}$ & $0.36 \pm 0.11 \mathrm{~B}$ & $97.0 \pm 28.7 \mathrm{~B}$ \\
\hline & $+\mathrm{M}$ & $1.81 \pm 0.14 \mathrm{~A}$ & $0.40 \pm 0.04 \mathrm{~A}$ & $0.22 \pm 0.02 \mathrm{~B}$ & $80.5 \pm 1.83 \mathrm{~A}$ & $48.0 \pm 9.84 \mathrm{~A}$ & $117 \pm 11.3 \mathrm{~A}$ & $0.61 \pm 0.09 \mathrm{~A}$ & $128 \pm 19.7 \mathrm{~A}$ \\
\hline \multicolumn{10}{|c|}{ Vernonia cognata } \\
\hline \multirow[t]{2}{*}{$\mathrm{L}$} & $-\mathrm{M}$ & $\dagger$ & $\dagger$ & $\dagger$ & $\dagger$ & $\dagger$ & $\dagger$ & $\dagger$ & $\dagger$ \\
\hline & $+\mathrm{M}$ & $0.09 \pm 0.03$ & $0.22 \pm 0.09$ & $2.30 \pm 0.85$ & $58.5 \pm 5.80$ & $15.1 \pm 9.16$ & $72.3 \pm 31.7$ & - & $15.4 \pm 6.19$ \\
\hline \multirow[t]{2}{*}{$\mathrm{H}$} & $-\mathrm{M}$ & $3.19 \pm 0.40 \mathrm{~A}$ & $0.67 \pm 0.12 \mathrm{~A}$ & $0.21 \pm 0.06 \mathrm{~A}$ & $86.0 \pm 1.02 \mathrm{~A}$ & $120 \pm 26.7 \mathrm{~A}$ & $180 \pm 42.8 \mathrm{~A}$ & - & $145 \pm 31.4 \mathrm{~B}$ \\
\hline & $+\mathrm{M}$ & $3.05 \pm 0.66 \mathrm{~A}$ & $0.87 \pm 0.16 \mathrm{~A}$ & $0.28 \pm 0.04 \mathrm{~A}$ & $85.0 \pm 2.66 \mathrm{~A}$ & $98.1 \pm 32.7 \mathrm{~A}$ & $140 \pm 30.8 \mathrm{~A}$ & - & $202 \pm 31.7 \mathrm{~A}$ \\
\hline \multicolumn{10}{|c|}{ Vernonia polyanthes } \\
\hline \multirow[t]{2}{*}{$\mathrm{L}$} & $-\mathrm{M}$ & $\#$ & $\#$ & \# & \# & $\#$ & $\#$ & $\#$ & $\#$ \\
\hline & $+\mathrm{M}$ & $0.10 \pm 0.04$ & $0.15 \pm 0.07$ & $1.39 \pm 0.59$ & $47.5 \pm 9.59$ & $24.6 \pm 11.2$ & $178 \pm 44.3$ & - & $20.6 \pm 8.53$ \\
\hline \multirow[t]{2}{*}{$\mathrm{H}$} & $-\mathrm{M}$ & $1.37 \pm 0.19 \mathrm{~A}$ & $1.94 \pm 0.29 \mathrm{~A}$ & $1.45 \pm 0.31 \mathrm{~A}$ & $55.0 \pm 2.18 \mathrm{~B}$ & $207 \pm 53.1 \mathrm{~A}$ & $104 \pm 13.2 \mathrm{~A}$ & - & $139 \pm 23.1 \mathrm{~B}$ \\
\hline & $+\mathrm{M}$ & $1.72 \pm 0.32 \mathrm{~A}$ & $2.02 \pm 0.39 \mathrm{~A}$ & $1.21 \pm 0.32 \mathrm{~A}$ & $64.3 \pm 5.70 \mathrm{~A}$ & $117 \pm 24.5 \mathrm{~B}$ & $58.6 \pm 11.9 \mathrm{~B}$ & - & $231 \pm 42.4 \mathrm{~A}$ \\
\hline \multicolumn{10}{|c|}{ Tecoma stans } \\
\hline \multirow[t]{2}{*}{$\mathrm{L}$} & $-\mathrm{M}$ & $0.03 \pm 0.01 b$ & $0.03 \pm 0.02 b$ & $1.35 \pm 0.70 \mathrm{a}$ & $28.3 \pm 2.90 \mathrm{~b}$ & $3.55 \pm 1.99 b$ & $102 \pm 24.9 a$ & - & $1.08 \pm 0.19 b$ \\
\hline & $+\mathrm{M}$ & $0.13 \pm 0.02 \mathrm{a}$ & $0.14 \pm 0.05 a$ & $1.00 \pm 0.16 \mathrm{a}$ & $41.4 \pm 2.87 \mathrm{a}$ & $10.9 \pm 2.57 \mathrm{a}$ & $81.7 \pm 8.54 \mathrm{a}$ & - & $18.8 \pm 6.3 a$ \\
\hline \multirow[t]{2}{*}{$\mathrm{H}$} & $-\mathrm{M}$ & $1.33 \pm 0.22 \mathrm{~A}$ & $1.67 \pm 0.22 \mathrm{~A}$ & $1.26 \pm 0.13 \mathrm{~A}$ & $67.5 \pm 1.32 \mathrm{~A}$ & $100 \pm 25.2 \mathrm{~A}$ & $60.9 \pm 18.6 \mathrm{~A}$ & - & $194 \pm 20.1 \mathrm{~A}$ \\
\hline & $+\mathrm{M}$ & $1.29 \pm 0.15 \mathrm{~A}$ & $1.52 \pm 0.23 \mathrm{~A}$ & $1.17 \pm 0.10 \mathrm{~A}$ & $67.6 \pm 3.21 \mathrm{~A}$ & $125 \pm 19.7 \mathrm{~A}$ & $83.5 \pm 17.9 \mathrm{~A}$ & - & $217 \pm 29.4 \mathrm{~A}$ \\
\hline
\end{tabular}


Appendix 1. Continued.

\begin{tabular}{|c|c|c|c|c|c|c|c|c|c|}
\hline Soil & AMF & $\begin{array}{c}\text { SDM } \\
(\mathrm{g})\end{array}$ & $\begin{array}{c}\text { RDM } \\
(\mathrm{g})\end{array}$ & $\begin{array}{c}\mathrm{R} / \mathrm{S} \\
\left(\mathrm{g} \mathrm{g}^{-1}\right)\end{array}$ & $\begin{array}{c}\text { RGR } \\
\left(\mathrm{mg} \mathrm{g}^{-1} \mathrm{~d}^{-1}\right)\end{array}$ & $\begin{array}{c}\text { TRL } \\
\text { (m per plant) }\end{array}$ & $\begin{array}{c}\text { SRL } \\
\left(\mathrm{m} \mathrm{g}^{-1}\right)\end{array}$ & $\begin{array}{c}\text { TFDW } \\
\text { (g per plant) }\end{array}$ & $\begin{array}{c}\text { TLA } \\
\left(\mathrm{cm}^{2} \text { per plant }\right)\end{array}$ \\
\hline \multicolumn{10}{|c|}{ Momordica charantia } \\
\hline \multirow[t]{2}{*}{$\mathrm{L}$} & $-\mathrm{M}$ & $0.20 \pm 0.09 b$ & $0.09 \pm 0.01 \mathrm{~b}$ & $0.54 \pm 0.23 \mathrm{a}$ & $48.0 \pm 4.90 \mathrm{a}$ & $27.9 \pm 13.7 \mathrm{a}$ & $314 \pm 190 \mathrm{a}$ & - & $21.5 \pm 12.0 \mathrm{a}$ \\
\hline & $+\mathrm{M}$ & $0.39 \pm 0.11 \mathrm{a}$ & $0.13 \pm 0.01 \mathrm{a}$ & $0.34 \pm 0.06 \mathrm{a}$ & $49.0 \pm 2.84 \mathrm{a}$ & $33.8 \pm 10.9 \mathrm{a}$ & $264 \pm 72.6 a$ & - & $34.5 \pm 9.43 a$ \\
\hline \multirow[t]{2}{*}{$\mathrm{H}$} & $-\mathrm{M}$ & $1.01 \pm 0.14 \mathrm{~A}$ & $0.37 \pm 0.05 \mathrm{~A}$ & $0.36 \pm 0.06 \mathrm{~A}$ & $59.3 \pm 4.88 \mathrm{~A}$ & $93.2 \pm 26.7 \mathrm{~A}$ & $251 \pm 51.6 \mathrm{~A}$ & - & $152 \pm 35.4 \mathrm{~B}$ \\
\hline & $+\mathrm{M}$ & $1.15 \pm 0.07 \mathrm{~A}$ & $0.42 \pm 0.06 \mathrm{~A}$ & $0.36 \pm 0.03 \mathrm{~A}$ & $63.7 \pm 3.37 \mathrm{~A}$ & $81.9 \pm 11.9 \mathrm{~A}$ & $195 \pm 35.4 \mathrm{~A}$ & $0.01 \pm 0.01$ & $228 \pm 19.3 \mathrm{~A}$ \\
\hline \multicolumn{10}{|c|}{ Chamaecrista nictitans } \\
\hline \multirow[t]{2}{*}{$\mathrm{L}$} & $-\mathrm{M}$ & $\dagger$ & $\dagger$ & $\dagger$ & $\dagger$ & $\dagger$ & $\dagger$ & $\dagger$ & $\dagger$ \\
\hline & $+\mathrm{M}$ & $0.15 \pm 0.07$ & $0.10 \pm 0.02$ & $0.85 \pm 0.44$ & $42.7 \pm 4.69$ & $10.7 \pm 5.15$ & $99.1 \pm 29.4$ & - & $17.5 \pm 9.81$ \\
\hline \multirow[t]{2}{*}{$\mathrm{H}$} & $-\mathrm{M}$ & $3.32 \pm 1.57 \mathrm{~A}$ & $0.66 \pm 0.21 \mathrm{~A}$ & $0.21 \pm 0.06 \mathrm{~A}$ & $75.1 \pm 7.83 \mathrm{~A}$ & $129 \pm 43.6 \mathrm{~A}$ & $195 \pm 16.3 \mathrm{~A}$ & $0.10 \pm 0.02 \mathrm{~B}$ & $240 \pm 66.5 \mathrm{~B}$ \\
\hline & $+\mathrm{M}$ & $3.88 \pm 1.24 \mathrm{~A}$ & $0.65 \pm 0.26 \mathrm{~A}$ & $0.17 \pm 0.03 \mathrm{~A}$ & $75.8 \pm 4.46 \mathrm{~A}$ & $53.1 \pm 16.2 \mathrm{~B}$ & $86.9 \pm 25.6 \mathrm{~B}$ & $0.18 \pm 0.04 \mathrm{~A}$ & $355 \pm 42.8 \mathrm{~A}$ \\
\hline \multicolumn{10}{|c|}{ Crotalaria incana } \\
\hline \multirow[t]{2}{*}{$\mathrm{L}$} & $-\mathrm{M}$ & $\dagger$ & $\dagger$ & $\dagger$ & $\dagger$ & $\dagger$ & $\dagger$ & $\dagger$ & $\dagger$ \\
\hline & $+\mathrm{M}$ & $0.20 \pm 0.04$ & $0.13 \pm 0.02$ & $0.65 \pm 0.05$ & $44.5 \pm 1.20$ & $24.6 \pm 2.85$ & $189 \pm 26.1$ & - & $28.4 \pm 5.73$ \\
\hline \multirow[t]{2}{*}{$\mathrm{H}$} & $-\mathrm{M}$ & $5.13 \pm 0.79 \mathrm{~B}$ & $2.40 \pm 0.58 \mathrm{~A}$ & $0.47 \pm 0.11 \mathrm{~A}$ & $76.7 \pm 4.19 \mathrm{~B}$ & $279 \pm 48.3 \mathrm{~A}$ & $120 \pm 26.9 \mathrm{~A}$ & $0.56 \pm 0.49 \mathrm{~A}$ & $408 \pm 45.1 B$ \\
\hline & $+\mathrm{M}$ & $8.21 \pm 1.53 \mathrm{~A}$ & $2.93 \pm 0.38 \mathrm{~A}$ & $0.36 \pm 0.05 \mathrm{~A}$ & $83.8 \pm 3.28 \mathrm{~A}$ & $381 \pm 142 \mathrm{~A}$ & $134 \pm 61.5 \mathrm{~A}$ & $1.80 \pm 1.20 \mathrm{~A}$ & $619 \pm 89.2 \mathrm{~A}$ \\
\hline \multicolumn{10}{|c|}{ Indigofera hirsuta } \\
\hline \multirow[t]{2}{*}{$\mathrm{L}$} & $-\mathrm{M}$ & $\dagger$ & $\dagger$ & $\dagger$ & $\dagger$ & $\dagger$ & $\dagger$ & $\dagger$ & $\dagger$ \\
\hline & $+\mathrm{M}$ & $0.03 \pm 0.04$ & $0.03 \pm 0.01$ & $1.14 \pm 0.15$ & $31.6 \pm 1.94$ & $5.79 \pm 1.92$ & $184 \pm 66.9$ & - & $3.56 \pm 0.10$ \\
\hline \multirow[t]{2}{*}{$\mathrm{H}$} & $-\mathrm{M}$ & $2.39 \pm 0.52 \mathrm{~B}$ & $0.63 \pm 0.16 \mathrm{~A}$ & $0.26 \pm 0.02 \mathrm{~A}$ & $69.4 \pm 4.45 \mathrm{~B}$ & $158 \pm 64.9 \mathrm{~A}$ & $240 \pm 36.3 \mathrm{~A}$ & $0.14 \pm 0.12 \mathrm{~A}$ & $278 \pm 40.0 \mathrm{~B}$ \\
\hline & $+\mathrm{M}$ & $4.87 \pm 0.58 \mathrm{~A}$ & $0.88 \pm 0.25 \mathrm{~A}$ & $0.18 \pm 0.03 \mathrm{~B}$ & $83.2 \pm 5.80 \mathrm{~A}$ & $150 \pm 77.7 \mathrm{~A}$ & $165 \pm 51.5 \mathrm{~B}$ & $0.36 \pm 0.21 \mathrm{~A}$ & $565 \pm 74.8 \mathrm{~A}$ \\
\hline \multicolumn{10}{|c|}{ Mimosa invisa } \\
\hline \multirow[t]{2}{*}{$\mathrm{L}$} & $-\mathrm{M}$ & $0.04 \pm 0.01 b$ & $0.06 \pm 0.01 b$ & $1.67 \pm 0.56 \mathrm{a}$ & $32.3 \pm 4.07 \mathrm{~b}$ & $6.89 \pm 1.91 b$ & $110 \pm 13.4 \mathrm{a}$ & - & $1.94 \pm 0.45 b$ \\
\hline & $+\mathrm{M}$ & $0.26 \pm 0.07 \mathrm{a}$ & $0.22 \pm 0.02 \mathrm{a}$ & $0.88 \pm 0.18 b$ & $47.4 \pm 4.49 \mathrm{a}$ & $12.6 \pm 1.22 \mathrm{a}$ & $56.8 \pm 6.77 \mathrm{~b}$ & - & $20.2 \pm 4.10 \mathrm{a}$ \\
\hline \multirow[t]{2}{*}{$\mathrm{H}$} & $-\mathrm{M}$ & $1.14 \pm 0.34 \mathrm{~A}$ & $1.06 \pm 0.12 \mathrm{~A}$ & $0.98 \pm 0.24 \mathrm{~A}$ & $62.9 \pm 3.62 \mathrm{~A}$ & $94.2 \pm 10.9 \mathrm{~A}$ & $89.5 \pm 12.7 \mathrm{~A}$ & - & $83.4 \pm 26.1 \mathrm{~A}$ \\
\hline & $+\mathrm{M}$ & $0.85 \pm 0.15 \mathrm{~A}$ & $0.73 \pm 0.11 \mathrm{~B}$ & $0.87 \pm 0.15 \mathrm{~A}$ & $58.8 \pm 1.61 \mathrm{~B}$ & $42.6 \pm 7.89 \mathrm{~B}$ & $58.1 \pm 6.87 \mathrm{~B}$ & - & $54.6 \pm 12.2 \mathrm{~A}$ \\
\hline \multicolumn{10}{|c|}{ Senna obtusifolia } \\
\hline \multirow[t]{2}{*}{$\mathrm{L}$} & $-\mathrm{M}$ & $0.02 \pm 0.01 b$ & $0.05 \pm 0.02 b$ & $2.15 \pm 1.50 \mathrm{a}$ & $25.3 \pm 2.47 b$ & $8.75 \pm 4.45 b$ & $169 \pm 30.1 \mathrm{a}$ & $0.01 \pm 0.01 b$ & $1.00 \pm 0.27 \mathrm{~b}$ \\
\hline & $+\mathrm{M}$ & $0.15 \pm 0.03 \mathrm{a}$ & $0.16 \pm 0.01 \mathrm{a}$ & $1.12 \pm 0.31 \mathrm{a}$ & $35.7 \pm 4.13 \mathrm{a}$ & $17.0 \pm 2.68 \mathrm{a}$ & $104 \pm 20.0 b$ & $0.02 \pm 0.01 \mathrm{a}$ & $19.6 \pm 5.71 \mathrm{a}$ \\
\hline \multirow[t]{2}{*}{$\mathrm{H}$} & $-\mathrm{M}$ & $1.52 \pm 0.35 \mathrm{~A}$ & $0.67 \pm 0.16 \mathrm{~A}$ & $0.43 \pm 0.05 \mathrm{~B}$ & $55.1 \pm 3.94 \mathrm{~A}$ & $78.5 \pm 29.7 \mathrm{~A}$ & $115 \pm 24.1 \mathrm{~A}$ & $0.03 \pm 0.01 \mathrm{~A}$ & $87.3 \pm 20.1 \mathrm{~A}$ \\
\hline & $+\mathrm{M}$ & $1.07 \pm 0.13 \mathrm{~B}$ & $0.59 \pm 0.12 \mathrm{~A}$ & $0.56 \pm 0.08 \mathrm{~A}$ & $50.2 \pm 1.65 \mathrm{~B}$ & $74.4 \pm 25.1 \mathrm{~A}$ & $123 \pm 24.7 \mathrm{~A}$ & $0.04 \pm 0.06 \mathrm{~A}$ & $112 \pm 15.5 \mathrm{~A}$ \\
\hline \multicolumn{10}{|c|}{ Hyptis spicigera } \\
\hline \multirow[t]{2}{*}{$\mathrm{L}$} & $-\mathrm{M}$ & $\dagger$ & $\dagger$ & $\dagger$ & $\dagger$ & $\dagger$ & $\dagger$ & $\dagger$ & $\dagger$ \\
\hline & $+\mathrm{M}$ & $0.06 \pm 0.01$ & $0.05 \pm 0.01$ & $0.79 \pm 0.16$ & $45.3 \pm 5.10$ & $16.0 \pm 5.76$ & $303 \pm 63.2$ & - & $8.66 \pm 2.54$ \\
\hline \multirow[t]{2}{*}{$\mathrm{H}$} & $-\mathrm{M}$ & $1.07 \pm 0.13 \mathrm{~A}$ & $1.19 \pm 0.12 \mathrm{~A}$ & $1.11 \pm 0.08 \mathrm{~A}$ & $68.7 \pm 3.83 \mathrm{~A}$ & $206 \pm 45.8 \mathrm{~A}$ & $171 \pm 23.5 \mathrm{~A}$ & - & $96.1 \pm 7.74 \mathrm{~B}$ \\
\hline & $+\mathrm{M}$ & $1.57 \pm 0.45 \mathrm{~A}$ & $1.44 \pm 0.51 \mathrm{~A}$ & $0.92 \pm 0.31 \mathrm{~A}$ & $74.7 \pm 6.71 \mathrm{~A}$ & $209 \pm 82.6 \mathrm{~A}$ & $148 \pm 28.5 \mathrm{~A}$ & $0.02 \pm 0.01$ & $165 \pm 22.9 \mathrm{~A}$ \\
\hline Leon & epetifolic & & & & & & & & \\
\hline $\mathrm{L}$ & $-\mathrm{M}$ & $\S$ & $\S$ & $\S$ & $\S$ & $\S$ & $\S$ & $\S$ & $\S$ \\
\hline & $+\mathrm{M}$ & $\dagger$ & $\dagger$ & $\dagger$ & $\dagger$ & $\dagger$ & $\dagger$ & $\dagger$ & $\dagger$ \\
\hline $\mathrm{H}$ & $-\mathrm{M}$ & $0.69 \pm 0.14 \mathrm{~B}$ & $0.28 \pm 0.05 \mathrm{~B}$ & $0.41 \pm 0.01 \mathrm{~A}$ & $71.8 \pm 2.22 \mathrm{~B}$ & $93.8 \pm 40.4 \mathrm{~A}$ & $323 \pm 93.0 \mathrm{~A}$ & $0.20 \pm 0.08 \mathrm{~B}$ & $61.0 \pm 13.2 \mathrm{~B}$ \\
\hline & $+\mathrm{M}$ & $1.81 \pm 0.16 \mathrm{~A}$ & $0.41 \pm 0.05 \mathrm{~A}$ & $0.23 \pm 0.03 \mathrm{~B}$ & $80.5 \pm 1.01 \mathrm{~A}$ & $112 \pm 21.7 \mathrm{~A}$ & $269 \pm 38.7 \mathrm{~A}$ & $0.66 \pm 0.08 \mathrm{~A}$ & $144 \pm 22.0 \mathrm{~A}$ \\
\hline Leon & ibiricus & & & & & & & & \\
\hline $\mathrm{L}$ & $-\mathrm{M}$ & $\dagger$ & $\dagger$ & $\dagger$ & $\dagger$ & $\dagger$ & $\dagger$ & $\dagger$ & $\dagger$ \\
\hline & $+\mathrm{M}$ & $0.03 \pm 0.01$ & $0.02 \pm 0.01$ & $0.63 \pm 0.17$ & $39.8 \pm 2.06$ & $4.91 \pm 0.74$ & $307 \pm 74.1$ & $0.01 \pm 0.01$ & $3.90 \pm 0.75$ \\
\hline $\mathrm{H}$ & $-\mathrm{M}$ & $0.34 \pm 0.06 \mathrm{~B}$ & $0.30 \pm 0.05 \mathrm{~B}$ & $0.89 \pm 0.08 \mathrm{~A}$ & $67.6 \pm 1.91 \mathrm{~B}$ & $79.9 \pm 12.7 \mathrm{~B}$ & $267 \pm 49.2 \mathrm{~A}$ & $0.07 \pm 0.03 \mathrm{~B}$ & $39.4 \pm 6.40 \mathrm{~B}$ \\
\hline & $+\mathrm{M}$ & $1.63 \pm 0.28 \mathrm{~A}$ & $0.86 \pm 0.07 \mathrm{~A}$ & $0.53 \pm 0.07 \mathrm{~B}$ & $81.6 \pm 1.39 \mathrm{~A}$ & $113 \pm 25.3 \mathrm{~A}$ & $131 \pm 25.2 \mathrm{~B}$ & $0.41 \pm 0.07 \mathrm{~A}$ & $159 \pm 13.3 \mathrm{~A}$ \\
\hline
\end{tabular}




\begin{tabular}{|c|c|c|c|c|c|c|c|c|c|}
\hline Soil & AMF & $\begin{array}{c}\text { SDM } \\
(\mathrm{g})\end{array}$ & $\begin{array}{c}\text { RDM } \\
(\mathrm{g})\end{array}$ & $\begin{array}{c}\mathrm{R} / \mathrm{S} \\
\left(\mathrm{g} \mathrm{g}^{-1}\right)\end{array}$ & $\begin{array}{c}\text { RGR } \\
\left(\mathrm{mg} \mathrm{g}^{-1} \mathrm{~d}^{-1}\right)\end{array}$ & $\begin{array}{c}\text { TRL } \\
\text { (m per plant) }\end{array}$ & $\begin{array}{c}\mathrm{SRL} \\
\left(\mathrm{mg}^{-1}\right)\end{array}$ & $\begin{array}{c}\text { TFDW } \\
\text { (g per plant) }\end{array}$ & $\begin{array}{c}\text { TLA } \\
\left(\mathrm{cm}^{2} \text { per plant }\right)\end{array}$ \\
\hline \multicolumn{10}{|c|}{ Sidastrum micranthum } \\
\hline \multirow[t]{2}{*}{$\mathrm{L}$} & $-\mathrm{M}$ & $\S$ & $\S$ & $\S$ & $\S$ & $\S$ & $\S$ & $\S$ & $\S$ \\
\hline & $+\mathrm{M}$ & $0.06 \pm 0.01$ & $0.08 \pm 0.05$ & $0.99 \pm 0.49$ & $53.0 \pm 3.87$ & $17.5 \pm 19.1$ & $191 \pm 100$ & - & $12.0 \pm 2.86$ \\
\hline \multirow[t]{2}{*}{$\mathrm{H}$} & $-\mathrm{M}$ & $1.59 \pm 0.33 \mathrm{~A}$ & $1.07 \pm 0.10 \mathrm{~A}$ & $0.69 \pm 0.08 \mathrm{~A}$ & $78.8 \pm 6.78 \mathrm{~A}$ & $147 \pm 72.3 \mathrm{~A}$ & $133 \pm 56.4 \mathrm{~A}$ & - & $112 \pm 21.4 \mathrm{~B}$ \\
\hline & $+\mathrm{M}$ & $1.66 \pm 0.13 \mathrm{~A}$ & $1.11 \pm 0.09 \mathrm{~A}$ & $0.66 \pm 0.03 \mathrm{~A}$ & $75.9 \pm 5.62 \mathrm{~A}$ & $135 \pm 55.8 \mathrm{~A}$ & $118 \pm 39.2 \mathrm{~A}$ & - & $155 \pm 9.47 \mathrm{~A}$ \\
\hline \multicolumn{10}{|c|}{ Cenchrus echinatus } \\
\hline \multirow[t]{2}{*}{$\mathrm{L}$} & $-\mathrm{M}$ & $0.02 \pm 0.01 b$ & $0.04 \pm 0.01 \mathrm{a}$ & $1.89 \pm 0.68 \mathrm{a}$ & $26.2 \pm 6.94 b$ & $18.3 \pm 9.49 a$ & $417 \pm 102 a$ & - & $4.58 \pm 1.90 b$ \\
\hline & $+\mathrm{M}$ & $0.20 \pm 0.06 a$ & $0.07 \pm 0.03 a$ & $0.39 \pm 0.12 b$ & $50.3 \pm 7.58 \mathrm{a}$ & $17.0 \pm 4.05 \mathrm{a}$ & $244 \pm 72.9 \mathrm{~b}$ & $0.01 \pm 0.01$ & $38.6 \pm 8.99 a$ \\
\hline \multirow[t]{2}{*}{$\mathrm{H}$} & $-\mathrm{M}$ & $1.58 \pm 0.16 \mathrm{~B}$ & $0.38 \pm 0.04 \mathrm{~A}$ & $0.24 \pm 0.03 \mathrm{~A}$ & $59.9 \pm 3.35 \mathrm{~A}$ & $91.4 \pm 10.7 \mathrm{~A}$ & $243 \pm 44.6 \mathrm{~A}$ & $0.38 \pm 0.05 \mathrm{~A}$ & $80.8 \pm 12.5 \mathrm{~B}$ \\
\hline & $+\mathrm{M}$ & $2.02 \pm 0.25 \mathrm{~A}$ & $0.41 \pm 0.13 \mathrm{~A}$ & $0.20 \pm 0.07 \mathrm{~A}$ & $65.7 \pm 5.77 \mathrm{~A}$ & $93.9 \pm 46.0 \mathrm{~A}$ & $275 \pm 221 \mathrm{~A}$ & $0.44 \pm 0.14 \mathrm{~A}$ & $190 \pm 32.8 \mathrm{~A}$ \\
\hline \multicolumn{10}{|c|}{ Chloris elata } \\
\hline \multirow[t]{2}{*}{$\mathrm{L}$} & $-\mathrm{M}$ & $0.01 \pm 0.01 \mathrm{~b}$ & $0.01 \pm 0.01 b$ & $1.29 \pm 0.53 \mathrm{a}$ & $29.6 \pm 4.83 b$ & $10.2 \pm 4.56 b$ & $936 \pm 381 a$ & - & $0.48 \pm 0.11 b$ \\
\hline & $+\mathrm{M}$ & $0.13 \pm 0.02 \mathrm{a}$ & $0.10 \pm 0.03 a$ & $0.76 \pm 0.13 a$ & $53.2 \pm 5.10 \mathrm{a}$ & $25.0 \pm 3.14 \mathrm{a}$ & $259 \pm 70.8 b$ & - & $18.7 \pm 2.53 a$ \\
\hline \multirow[t]{2}{*}{$\mathrm{H}$} & $-\mathrm{M}$ & $1.24 \pm 0.28 \mathrm{~A}$ & $0.77 \pm 0.16 \mathrm{~A}$ & $0.62 \pm 0.09 \mathrm{~A}$ & $67.9 \pm 8.40 \mathrm{~A}$ & $129 \pm 30.4 \mathrm{~A}$ & $168 \pm 15.6 \mathrm{~A}$ & - & $134 \pm 33.1 \mathrm{~A}$ \\
\hline & $+\mathrm{M}$ & $1.46 \pm 0.42 \mathrm{~A}$ & $0.56 \pm 0.16 \mathrm{~A}$ & $0.38 \pm 0.02 \mathrm{~B}$ & $67.1 \pm 8.11 \mathrm{~A}$ & $66.3 \pm 31.3 \mathrm{~B}$ & $114 \pm 30.8 \mathrm{~B}$ & - & $138 \pm 36.5 \mathrm{~A}$ \\
\hline \multicolumn{10}{|c|}{ Digitaria insularis } \\
\hline \multirow[t]{2}{*}{$\mathrm{L}$} & $-\mathrm{M}$ & $\dagger$ & $\dagger$ & $\dagger$ & $\dagger$ & $\dagger$ & $\dagger$ & $\dagger$ & $\dagger$ \\
\hline & $+\mathrm{M}$ & $0.18 \pm 0.06$ & $0.14 \pm 0.05$ & $0.78 \pm 0.07$ & $57.4 \pm 7.72$ & $26.8 \pm 5.55$ & $192 \pm 56.1$ & - & $21.5 \pm 6.32$ \\
\hline \multirow[t]{2}{*}{$\mathrm{H}$} & $-\mathrm{M}$ & $1.00 \pm 0.11 \mathrm{~B}$ & $0.50 \pm 0.15 \mathrm{~A}$ & $0.49 \pm 0.12 \mathrm{~A}$ & $75.5 \pm 1.84 \mathrm{~A}$ & $115 \pm 42.2 \mathrm{~A}$ & $228 \pm 37.5 \mathrm{~A}$ & $0.16 \pm 0.03 \mathrm{~B}$ & $52.2 \pm 16.5 \mathrm{~A}$ \\
\hline & $+\mathrm{M}$ & $1.55 \pm 0.26 \mathrm{~A}$ & $0.66 \pm 0.10 \mathrm{~A}$ & $0.43 \pm 0.07 \mathrm{~A}$ & $72.7 \pm 5.17 \mathrm{~A}$ & $148 \pm 50.3 \mathrm{~A}$ & $220 \pm 41.2 \mathrm{~A}$ & $0.32 \pm 0.12 \mathrm{~A}$ & $57.3 \pm 13.1 \mathrm{~A}$ \\
\hline \multicolumn{10}{|c|}{ Eragrostis pilosa } \\
\hline \multirow[t]{2}{*}{$\mathrm{L}$} & $-\mathrm{M}$ & $\S$ & $\S$ & $\S$ & $\S$ & $\S$ & $\S$ & $\S$ & $\S$ \\
\hline & $+\mathrm{M}$ & $0.09 \pm 0.06$ & $0.09 \pm 0.05$ & $0.99 \pm 0.49$ & $53.6 \pm 5.30$ & $32.9 \pm 20.7$ & $368 \pm 100$ & $0.07 \pm 0.02$ & $9.89 \pm 8.56$ \\
\hline \multirow[t]{2}{*}{$\mathrm{H}$} & $-\mathrm{M}$ & $0.69 \pm 0.23 \mathrm{~B}$ & $0.19 \pm 0.08 \mathrm{~B}$ & $0.29 \pm 0.10 \mathrm{~A}$ & $70.4 \pm 4.19 \mathrm{~B}$ & $107 \pm 29.6 \mathrm{~B}$ & $584 \pm 147 \mathrm{~A}$ & $0.27 \pm 0.14 \mathrm{~A}$ & $35.7 \pm 10.1 \mathrm{~B}$ \\
\hline & $+\mathrm{M}$ & $1.36 \pm 0.27 \mathrm{~A}$ & $0.50 \pm 0.04 \mathrm{~A}$ & $0.38 \pm 0.08 \mathrm{~A}$ & $78.7 \pm 1.03 \mathrm{~A}$ & $243 \pm 79.3 \mathrm{~A}$ & $471 \pm 124 \mathrm{~A}$ & $0.41 \pm 0.28 \mathrm{~A}$ & $91.4 \pm 20.3 \mathrm{~A}$ \\
\hline \multicolumn{10}{|c|}{ Melinis minutiflora } \\
\hline \multirow[t]{2}{*}{$\mathrm{L}$} & $-\mathrm{M}$ & $\dagger$ & $\dagger$ & $\dagger$ & $\dagger$ & $\dagger$ & $\dagger$ & $\dagger$ & $\dagger$ \\
\hline & $+\mathrm{M}$ & $0.17 \pm 0.02$ & $0.19 \pm 0.03$ & $1.14 \pm 0.19$ & $57.9 \pm 5.39$ & $75.3 \pm 34.2$ & $387 \pm 187$ & - & $32.9 \pm 4.65$ \\
\hline \multirow[t]{2}{*}{$\mathrm{H}$} & $-\mathrm{M}$ & $2.35 \pm 0.55 \mathrm{~A}$ & $1.13 \pm 0.28 \mathrm{~B}$ & $0.51 \pm 0.20 \mathrm{~A}$ & $73.7 \pm 9.47 \mathrm{~A}$ & $381 \pm 100 \mathrm{~A}$ & $335 \pm 38.9 \mathrm{~A}$ & - & $222 \pm 59.1 \mathrm{~A}$ \\
\hline & $+\mathrm{M}$ & $2.45 \pm 0.32 \mathrm{~A}$ & $1.60 \pm 0.15 \mathrm{~A}$ & $0.65 \pm 0.04 \mathrm{~A}$ & $74.6 \pm 7.07 \mathrm{~A}$ & $385 \pm 113 \mathrm{~A}$ & $239 \pm 62.7 \mathrm{~B}$ & - & $251 \pm 14.3 \mathrm{~A}$ \\
\hline \multicolumn{10}{|c|}{ Melinis repens } \\
\hline $\mathrm{L}$ & $-\mathrm{M}$ & $\dagger$ & $\dagger$ & $\dagger$ & $\dagger$ & $\dagger$ & $\dagger$ & $\dagger$ & $\dagger$ \\
\hline & $+\mathrm{M}$ & $0.14 \pm 0.06$ & $0.15 \pm 0.05$ & $1.07 \pm 0.18$ & $59.0 \pm 3.95$ & $39.6 \pm 14.5$ & $268 \pm 53.7$ & - & $30.4 \pm 11.4$ \\
\hline $\mathrm{H}$ & $-\mathrm{M}$ & $3.01 \pm 1.26 \mathrm{~A}$ & $1.81 \pm 0.65 \mathrm{~A}$ & $0.61 \pm 0.06 \mathrm{~A}$ & $87.0 \pm 4.29 \mathrm{~A}$ & $341 \pm 141 \mathrm{~A}$ & $201 \pm 88.3 \mathrm{~A}$ & $0.17 \pm 0.08 \mathrm{~A}$ & $230 \pm 126 \mathrm{~A}$ \\
\hline & $+\mathrm{M}$ & $2.41 \pm 0.10 \mathrm{~A}$ & $0.97 \pm 0.11 \mathrm{~B}$ & $0.40 \pm 0.06 \mathrm{~B}$ & $84.2 \pm 1.65 \mathrm{~A}$ & $119 \pm 35.6 \mathrm{~B}$ & $122 \pm 36.7 \mathrm{~A}$ & $0.23 \pm 0.06 \mathrm{~A}$ & $208 \pm 18.9 \mathrm{~A}$ \\
\hline Penn & n ритре & & & & & & & & \\
\hline $\mathrm{L}$ & $-\mathrm{M}$ & $\S$ & $\S$ & $\S$ & $\S$ & $\S$ & $\S$ & $\S$ & $\S$ \\
\hline & $+\mathrm{M}$ & $0.12 \pm 0.05$ & $0.15 \pm 0.08$ & $1.22 \pm 0.39$ & $55.7 \pm 5.89$ & $41.0 \pm 18.2$ & $283 \pm 66.8$ & - & $25.0 \pm 9.52$ \\
\hline $\mathrm{H}$ & $-\mathrm{M}$ & $2.15 \pm 0.44 \mathrm{~A}$ & $1.75 \pm 0.71 \mathrm{~A}$ & $0.79 \pm 0.20 \mathrm{~A}$ & $81.1 \pm 8.07 \mathrm{~A}$ & $358 \pm 252 \mathrm{~A}$ & $193 \pm 93.5 \mathrm{~A}$ & - & $181 \pm 30.2 \mathrm{~A}$ \\
\hline & $+\mathrm{M}$ & $2.03 \pm 0.35 \mathrm{~A}$ & $1.50 \pm 0.14 \mathrm{~A}$ & $0.76 \pm 0.18 \mathrm{~A}$ & $81.3 \pm 3.42 \mathrm{~A}$ & $318 \pm 71.2 \mathrm{~A}$ & $210 \pm 39.3 \mathrm{~A}$ & - & $168 \pm 19.1 \mathrm{~A}$ \\
\hline Sorgl & rundin & & & & & & & & \\
\hline $\mathrm{L}$ & $-\mathrm{M}$ & $\dagger$ & $\dagger$ & $\dagger$ & $\dagger$ & $\dagger$ & $\dagger$ & $\dagger$ & $\dagger$ \\
\hline & $+\mathrm{M}$ & $0.16 \pm 0.06$ & $0.21 \pm 0.09$ & $1.26 \pm 0.40$ & $45.5 \pm 10.4$ & $42.9 \pm 19.6$ & $161 \pm 42.6$ & - & $35.1 \pm 17.8$ \\
\hline $\mathrm{H}$ & $-\mathrm{M}$ & $2.09 \pm 0.49 \mathrm{~B}$ & $0.64 \pm 0.09 \mathrm{~B}$ & $0.31 \pm 0.05 \mathrm{~A}$ & $73.7 \pm 12.9 \mathrm{~A}$ & $200 \pm 16.3 \mathrm{~A}$ & $318 \pm 61.8 \mathrm{~A}$ & $0.34 \pm 0.11 \mathrm{~B}$ & $97.1 \pm 22.2 \mathrm{~B}$ \\
\hline & $+\mathrm{M}$ & $2.80 \pm 0.32 \mathrm{~A}$ & $0.82 \pm 0.06 \mathrm{~A}$ & $0.29 \pm 0.03 \mathrm{~A}$ & $73.4 \pm 10.4 \mathrm{~A}$ & $145 \pm 51.2 \mathrm{~A}$ & $174 \pm 49.5 \mathrm{~B}$ & $0.63 \pm 0.19 \mathrm{~A}$ & $261 \pm 14.4 \mathrm{~A}$ \\
\hline Solar & iarum & & & & & & & & \\
\hline $\mathrm{L}$ & $-\mathrm{M}$ & $0.01 \pm 0.01 b$ & $0.01 \pm 0.01 b$ & $0.83 \pm 0.36 \mathrm{a}$ & $28.9 \pm 4.84 b$ & $4.80 \pm 0.67 b$ & $547 \pm 209 a$ & - & $0.24 \pm 0.08 b$ \\
\hline & $+\mathrm{M}$ & $0.06 \pm 0.04 \mathrm{a}$ & $0.07 \pm 0.04 \mathrm{a}$ & $1.17 \pm 0.51 \mathrm{a}$ & $49.2 \pm 5.63 \mathrm{a}$ & $11.8 \pm 3.43 \mathrm{~A}$ & $190 \pm 41.4 b$ & - & $7.29 \pm 4.93 \mathrm{a}$ \\
\hline $\mathrm{H}$ & $-\mathrm{M}$ & $1.10 \pm 0.11 \mathrm{~A}$ & $1.79 \pm 0.46 \mathrm{~A}$ & $1.63 \pm 0.43 \mathrm{~A}$ & $78.4 \pm 6.19 \mathrm{~A}$ & $206 \pm 32.4 \mathrm{~A}$ & $119 \pm 24.2 \mathrm{~A}$ & - & $125 \pm 15.6 \mathrm{~A}$ \\
\hline & $+\mathrm{M}$ & $0.92 \pm 0.16 \mathrm{~A}$ & $1.63 \pm 0.22 \mathrm{~A}$ & $1.83 \pm 0.53 \mathrm{~A}$ & $78.0 \pm 3.47 \mathrm{~A}$ & $137 \pm 19.9 \mathrm{~B}$ & $84.6 \pm 12.1 \mathrm{~B}$ & - & $130 \pm 22.7 \mathrm{~A}$ \\
\hline
\end{tabular}


Appendix 2. Mean $( \pm \mathrm{SD})$ for nutrient concentration in shoots of herbaceous and shrubby species of early stages of tropical succession grown in the high-fertility soil, without $(-\mathrm{M})$ or with $(+\mathrm{M})$ AMF. Means followed by the same letter do not differ by Student's $t$-test at $\mathrm{P}<0.05(n=3)$.

\begin{tabular}{|c|c|c|c|c|c|}
\hline$\overline{\mathrm{AMF}}$ & Phosphorus ( $\mathrm{g} \mathrm{kg}^{-1}$ ) & Nitrogen $\left(\mathrm{g} \mathrm{kg}^{-1}\right)$ & Potassium $\left(\mathrm{g} \mathrm{kg}^{-1}\right)$ & Calcium $\left(\mathrm{g} \mathrm{kg}^{-1}\right)$ & Magnesium $\left(\mathrm{g} \mathrm{kg}^{-1}\right)$ \\
\hline \multicolumn{6}{|c|}{$\overline{\text { Amaranthus hybridus }}$} \\
\hline$-\mathrm{M}$ & $4.55 \pm 0.54 \mathrm{a}$ & $38.3 \pm 1.48 \mathrm{a}$ & $38.3 \pm 1.48 \mathrm{a}$ & $1.37 \pm 0.13 \mathrm{a}$ & $0.71 \pm 0.03 \mathrm{a}$ \\
\hline$+\mathrm{M}$ & $4.30 \pm 0.14 \mathrm{a}$ & $38.5 \pm 0.97 a$ & $38.5 \pm 0.97 a$ & $1.62 \pm 0.28 \mathrm{a}$ & $0.73 \pm 0.02 \mathrm{a}$ \\
\hline \multicolumn{6}{|c|}{ Asclepias curassavica } \\
\hline$-\mathrm{M}$ & $1.58 \pm 0.11 b$ & $26.1 \pm 2.29 a$ & $26.1 \pm 2.29 a$ & $1.22 \pm 0.08 b$ & $0.24 \pm 0.01 b$ \\
\hline$+\mathrm{M}$ & $4.20 \pm 0.06 \mathrm{a}$ & $29.9 \pm 1.01 \mathrm{a}$ & $29.9 \pm 1.01 \mathrm{a}$ & $1.75 \pm 0.10 \mathrm{a}$ & $0.48 \pm 0.02 \mathrm{a}$ \\
\hline \multicolumn{6}{|c|}{ Baccharis sp. } \\
\hline$-\mathrm{M}$ & $1.31 \pm 0.05 b$ & $30.7 \pm 1.08 \mathrm{a}$ & $30.7 \pm 1.08 \mathrm{a}$ & $2.46 \pm 0.16 \mathrm{a}$ & $0.40 \pm 0.02 \mathrm{a}$ \\
\hline$+\mathrm{M}$ & $2.57 \pm 0.15 \mathrm{a}$ & $29.0 \pm 0.94 a$ & $29.0 \pm 0.94 a$ & $2.14 \pm 0.28 \mathrm{a}$ & $0.37 \pm 0.01 \mathrm{a}$ \\
\hline \multicolumn{6}{|c|}{ Hypochaeris brasiliensis } \\
\hline$-\mathrm{M}$ & $3.77 \pm 0.09 b$ & $46.5 \pm 0.98 \mathrm{a}$ & $46.5 \pm 0.98 \mathrm{a}$ & $5.64 \pm 0.22 \mathrm{a}$ & $0.96 \pm 0.01 b$ \\
\hline$+\mathrm{M}$ & $6.68 \pm 0.16 a$ & $47.8 \pm 0.94 \mathrm{a}$ & $47.8 \pm 0.94 \mathrm{a}$ & $5.77 \pm 0.21 \mathrm{a}$ & $1.19 \pm 0.02 \mathrm{a}$ \\
\hline \multicolumn{6}{|c|}{ Porophyllum ruderale } \\
\hline$-\mathrm{M}$ & $1.41 \pm 0.06 b$ & $18.9 \pm 1.18 \mathrm{a}$ & $18.9 \pm 1.18 \mathrm{a}$ & $3.25 \pm 0.10 \mathrm{a}$ & $0.53 \pm 0.02 \mathrm{a}$ \\
\hline$+\mathrm{M}$ & $3.04 \pm 0.28 \mathrm{a}$ & $15.8 \pm 2.05 \mathrm{a}$ & $15.8 \pm 2.05 \mathrm{a}$ & $3.34 \pm 0.03 \mathrm{a}$ & $0.53 \pm 0.02 \mathrm{a}$ \\
\hline \multicolumn{6}{|c|}{ Vernonia cognata } \\
\hline$-\mathrm{M}$ & $3.97 \pm 0.15 b$ & $15.5 \pm 1.00 \mathrm{~b}$ & $15.5 \pm 1.00 \mathrm{~b}$ & $4.42 \pm 0.44 \mathrm{a}$ & $0.34 \pm 0.04 \mathrm{~b}$ \\
\hline$+\mathrm{M}$ & $6.39 \pm 0.12 \mathrm{a}$ & $24.3 \pm 1.21 \mathrm{a}$ & $24.3 \pm 1.21 \mathrm{a}$ & $3.77 \pm 0.33 \mathrm{a}$ & $0.40 \pm 0.02 \mathrm{a}$ \\
\hline \multicolumn{6}{|c|}{ Vernonia polyanthes } \\
\hline$-\mathrm{M}$ & $1.63 \pm 0.10 b$ & $14.4 \pm 0.94 b$ & $14.4 \pm 0.94 b$ & $5.37 \pm 0.13 a$ & $0.56 \pm 0.01 b$ \\
\hline$+\mathrm{M}$ & $2.76 \pm 0.25 \mathrm{a}$ & $18.0 \pm 0.71 \mathrm{a}$ & $18.0 \pm 0.71 \mathrm{a}$ & $5.00 \pm 0.31 \mathrm{a}$ & $0.76 \pm 0.03 a$ \\
\hline \multicolumn{6}{|c|}{ Tecoma stans } \\
\hline$-\mathrm{M}$ & $1.70 \pm 0.11 \mathrm{~b}$ & $17.5 \pm 0.73 \mathrm{~b}$ & $17.5 \pm 0.73 b$ & $0.81 \pm 0.02 b$ & $0.11 \pm 0.01 b$ \\
\hline$+\mathrm{M}$ & $3.83 \pm 0.02 \mathrm{a}$ & $21.2 \pm 0.69 \mathrm{a}$ & $21.2 \pm 0.69 \mathrm{a}$ & $0.95 \pm 0.01 \mathrm{a}$ & $0.19 \pm 0.01 \mathrm{a}$ \\
\hline \multicolumn{6}{|c|}{ Momordica charantia } \\
\hline$-\mathrm{M}$ & $3.07 \pm 0.16 b$ & $28.2 \pm 0.98 b$ & $28.2 \pm 0.98 b$ & $10.4 \pm 0.21 b$ & $1.07 \pm 0.01 \mathrm{a}$ \\
\hline$+\mathrm{M}$ & $4.66 \pm 0.13 a$ & $31.5 \pm 0.71 \mathrm{a}$ & $31.5 \pm 0.71 \mathrm{a}$ & $11.4 \pm 0.06 \mathrm{a}$ & $1.14 \pm 0.05 \mathrm{a}$ \\
\hline \multicolumn{6}{|c|}{ Chamaecrista nictitans } \\
\hline$-\mathrm{M}$ & $1.15 \pm 0.06 b$ & $13.1 \pm 0.71 \mathrm{a}$ & $13.1 \pm 0.71 \mathrm{a}$ & $1.31 \pm 0.16 \mathrm{a}$ & $0.17 \pm 0.02 \mathrm{a}$ \\
\hline$+\mathrm{M}$ & $1.68 \pm 0.07 \mathrm{a}$ & $12.5 \pm 0.47 \mathrm{a}$ & $12.5 \pm 0.47 \mathrm{a}$ & $1.10 \pm 0.01 \mathrm{a}$ & $0.17 \pm 0.01 \mathrm{a}$ \\
\hline \multicolumn{6}{|c|}{ Crotalaria incana } \\
\hline$-\mathrm{M}$ & $1.09 \pm 0.11 \mathrm{~b}$ & $6.70 \pm 0.27 \mathrm{a}$ & $6.70 \pm 0.27 \mathrm{a}$ & $1.90 \pm 0.07 \mathrm{a}$ & $1.03 \pm 0.02 \mathrm{a}$ \\
\hline$+\mathrm{M}$ & $2.30 \pm 0.10 \mathrm{a}$ & $7.02 \pm 0.54 \mathrm{a}$ & $7.02 \pm 0.54 \mathrm{a}$ & $1.83 \pm 0.33 \mathrm{a}$ & $0.96 \pm 0.04 a$ \\
\hline \multicolumn{6}{|c|}{ Indigofera hirsuta } \\
\hline$-M$ & $3.10 \pm 0.26 \mathrm{a}$ & $9.84 \pm 0.27 b$ & $9.84 \pm 0.27 b$ & $3.15 \pm 0.25 \mathrm{a}$ & $0.61 \pm 0.01 \mathrm{a}$ \\
\hline$+\mathrm{M}$ & $2.82 \pm 0.17 \mathrm{a}$ & $11.8 \pm 0.27 \mathrm{a}$ & $11.8 \pm 0.27 \mathrm{a}$ & $2.58 \pm 0.03 b$ & $0.41 \pm 0.01 b$ \\
\hline \multicolumn{6}{|c|}{ Mimosa invisa } \\
\hline$-\mathrm{M}$ & $1.75 \pm 0.02 \mathrm{~b}$ & $4.04 \pm 1.28 \mathrm{~b}$ & $4.04 \pm 1.28 \mathrm{~b}$ & $4.12 \pm 0.14 \mathrm{a}$ & $0.43 \pm 0.01 \mathrm{a}$ \\
\hline$+\mathrm{M}$ & $5.81 \pm 0.16 \mathrm{a}$ & $9.62 \pm 0.64 \mathrm{a}$ & $9.62 \pm 0.64 a$ & $3.87 \pm 0.19 a$ & $0.33 \pm 0.01 b$ \\
\hline \multicolumn{6}{|c|}{ Senna obtusifolia } \\
\hline$-\mathrm{M}$ & $1.93 \pm 0.04 b$ & $12.1 \pm 0.74 \mathrm{a}$ & $12.1 \pm 0.74 \mathrm{a}$ & $2.49 \pm 0.28 b$ & $0.19 \pm 0.01 b$ \\
\hline$+\mathrm{M}$ & $3.31 \pm 0.36 \mathrm{a}$ & $13.4 \pm 0.74 a$ & $13.4 \pm 0.74 a$ & $3.10 \pm 0.19 \mathrm{a}$ & $0.24 \pm 0.01 \mathrm{a}$ \\
\hline \multicolumn{6}{|c|}{ Hyptis spicigera } \\
\hline$-\mathrm{M}$ & $3.91 \pm 0.41 b$ & $10.3 \pm 0.48 \mathrm{a}$ & $10.3 \pm 0.48 \mathrm{a}$ & $2.68 \pm 0.06 a$ & $0.42 \pm 0.08 \mathrm{a}$ \\
\hline$+\mathrm{M}$ & $7.15 \pm 0.09 a$ & $11.9 \pm 1.22 \mathrm{a}$ & $11.9 \pm 1.22 \mathrm{a}$ & $2.42 \pm 0.20 \mathrm{a}$ & $0.41 \pm 0.02 \mathrm{a}$ \\
\hline \multicolumn{6}{|c|}{ Leonotis nepetifolia } \\
\hline$-\mathrm{M}$ & $2.15 \pm 0.27 b$ & $19.5 \pm 2.05 a$ & $19.5 \pm 2.05 a$ & $2.53 \pm 0.90 \mathrm{a}$ & $0.32 \pm 0.06 \mathrm{a}$ \\
\hline$+\mathrm{M}$ & $5.72 \pm 0.08 \mathrm{a}$ & $19.9 \pm 0.72 \mathrm{a}$ & $19.9 \pm 0.72 \mathrm{a}$ & $2.23 \pm 0.04 \mathrm{a}$ & $0.33 \pm 0.02 \mathrm{a}$ \\
\hline Leonul & & & & & \\
\hline$-\mathrm{M}$ & $2.43 \pm 0.06 b$ & $20.9 \pm 0.78 b$ & $20.9 \pm 0.78 b$ & $1.72 \pm 0.19 \mathrm{~b}$ & $0.49 \pm 0.03 b$ \\
\hline$+\mathrm{M}$ & $3.88 \pm 0.25 \mathrm{a}$ & $24.7 \pm 0.74 a$ & $24.7 \pm 0.74 a$ & $2.40 \pm 0.06 \mathrm{a}$ & $0.64 \pm 0.01 \mathrm{a}$ \\
\hline Sidast & hum & & & & \\
\hline$-\mathrm{M}$ & $4.35 \pm 0.02 b$ & $15.8 \pm 0.47 \mathrm{a}$ & $15.8 \pm 0.47 \mathrm{a}$ & $9.11 \pm 0.23 a$ & $0.75 \pm 0.01 b$ \\
\hline$+\mathrm{M}$ & $7.83 \pm 0.29 a$ & $16.6 \pm 0.54 \mathrm{a}$ & $16.6 \pm 0.54 \mathrm{a}$ & $9.12 \pm 0.08 \mathrm{a}$ & $0.86 \pm 0.03 a$ \\
\hline Cench & & & & & \\
\hline$-\mathrm{M}$ & $1.55 \pm 0.15 b$ & $32.6 \pm 0.97 b$ & $32.6 \pm 0.97 b$ & $0.18 \pm 0.02 \mathrm{a}$ & $0.10 \pm 0.01 b$ \\
\hline$+\mathrm{M}$ & $5.01 \pm 0.15 \mathrm{a}$ & $35.3 \pm 0.24 a$ & $35.3 \pm 0.24 a$ & $0.14 \pm 0.02 \mathrm{a}$ & $0.19 \pm 0.01 \mathrm{a}$ \\
\hline Chlori & & & & & \\
\hline$-\mathrm{M}$ & $1.25 \pm 0.17 b$ & $14.4 \pm 0.74 \mathrm{a}$ & $14.4 \pm 0.74 \mathrm{a}$ & $0.41 \pm 0.01 \mathrm{a}$ & $0.24 \pm 0.02 \mathrm{a}$ \\
\hline$+\mathrm{M}$ & $2.81 \pm 0.45 \mathrm{a}$ & $15.8 \pm 0.73 a$ & $15.8 \pm 0.73 a$ & $0.24 \pm 0.01 b$ & $0.15 \pm 0.02 b$ \\
\hline
\end{tabular}


Appendix 2. Continued.

\begin{tabular}{|c|c|c|c|c|c|}
\hline$\overline{\mathrm{AMF}}$ & Phosphorus $\left(\mathrm{g} \mathrm{kg}^{-1}\right)$ & Nitrogen $\left(\mathrm{g} \mathrm{kg}^{-1}\right)$ & Potassium $\left(\mathrm{g} \mathrm{kg}^{-1}\right)$ & Calcium $\left(\mathrm{g} \mathrm{kg}^{-1}\right)$ & Magnesium $\left(\mathrm{g} \mathrm{kg}^{-1}\right)$ \\
\hline \multicolumn{6}{|c|}{ Digitaria insularis } \\
\hline$-\mathrm{M}$ & $3.09 \pm 0.14 b$ & $19.4 \pm 0.74 b$ & $19.4 \pm 0.74 b$ & $0.35 \pm 0.02 \mathrm{a}$ & $0.27 \pm 0.01 a$ \\
\hline$+\mathrm{M}$ & $3.63 \pm 0.13 a$ & $24.2 \pm 1.48 \mathrm{a}$ & $24.2 \pm 1.48 \mathrm{a}$ & $0.29 \pm 0.04 b$ & $0.16 \pm 0.02 b$ \\
\hline \multicolumn{6}{|c|}{ Eragrostis pilosa } \\
\hline$-\mathrm{M}$ & $2.19 \pm 0.09 b$ & $15.7 \pm 0.45 b$ & $15.7 \pm 0.45 b$ & $0.23 \pm 0.06 a$ & $0.22 \pm 0.01 \mathrm{a}$ \\
\hline$+\mathrm{M}$ & $2.72 \pm 0.05 \mathrm{a}$ & $18.4 \pm 0.74 \mathrm{a}$ & $18.4 \pm 0.74 \mathrm{a}$ & $0.18 \pm 0.02 \mathrm{a}$ & $0.16 \pm 0.01 b$ \\
\hline \multicolumn{6}{|c|}{ Melinis minutiflora } \\
\hline$-\mathrm{M}$ & $3.67 \pm 0.34 \mathrm{a}$ & $13.7 \pm 0.51 b$ & $13.7 \pm 0.51 b$ & $0.27 \pm 0.11 \mathrm{a}$ & $0.45 \pm 0.01 \mathrm{a}$ \\
\hline$+\mathrm{M}$ & $4.68 \pm 0.09 \mathrm{a}$ & $16.3 \pm 0.74 a$ & $16.3 \pm 0.74 a$ & $0.34 \pm 0.03 a$ & $0.36 \pm 0.01 b$ \\
\hline \multicolumn{6}{|c|}{ Melinis repens } \\
\hline$-\mathrm{M}$ & $3.06 \pm 0.05 b$ & $14.5 \pm 0.21 \mathrm{a}$ & $14.5 \pm 0.21 \mathrm{a}$ & $0.25 \pm 0.01 \mathrm{a}$ & $0.29 \pm 0.04 \mathrm{a}$ \\
\hline$+\mathrm{M}$ & $4.70 \pm 0.21 \mathrm{a}$ & $15.1 \pm 0.98 \mathrm{a}$ & $15.1 \pm 0.98 \mathrm{a}$ & $0.21 \pm 0.02 \mathrm{a}$ & $0.23 \pm 0.03 a$ \\
\hline \multicolumn{6}{|c|}{ Pennisetum purpureum } \\
\hline$-\mathrm{M}$ & $2.62 \pm 0.28 \mathrm{a}$ & $26.3 \pm 1.18 b$ & $26.3 \pm 1.18 b$ & $0.28 \pm 0.06 a$ & $0.14 \pm 0.02 \mathrm{a}$ \\
\hline$+\mathrm{M}$ & $2.24 \pm 0.34 \mathrm{a}$ & $30.7 \pm 0.72 \mathrm{a}$ & $30.7 \pm 0.72 \mathrm{a}$ & $0.30 \pm 0.01 a$ & $0.12 \pm 0.01 \mathrm{a}$ \\
\hline \multicolumn{6}{|c|}{ Sorghum arundinaceum } \\
\hline$-\mathrm{M}$ & $1.70 \pm 0.22 b$ & $21.5 \pm 2.91 \mathrm{a}$ & $21.5 \pm 2.91 \mathrm{a}$ & $0.57 \pm 0.02 b$ & $0.27 \pm 0.01 b$ \\
\hline$+\mathrm{M}$ & $3.59 \pm 0.08 \mathrm{a}$ & $18.8 \pm 3.02 \mathrm{a}$ & $18.8 \pm 3.02 \mathrm{a}$ & $0.84 \pm 0.03 a$ & $0.49 \pm 0.02 \mathrm{a}$ \\
\hline \multicolumn{6}{|c|}{ Solanum viarum } \\
\hline$-\mathrm{M}$ & $1.72 \pm 0.29 b$ & $24.4 \pm 0.72 \mathrm{a}$ & $24.4 \pm 0.72 \mathrm{a}$ & $3.56 \pm 0.18 \mathrm{a}$ & $0.42 \pm 0.02 \mathrm{a}$ \\
\hline$+\mathrm{M}$ & $6.75 \pm 0.51 \mathrm{a}$ & $25.5 \pm 0.54 \mathrm{a}$ & $25.5 \pm 0.54 \mathrm{a}$ & $3.19 \pm 0.27 \mathrm{a}$ & $0.45 \pm 0.01 a$ \\
\hline
\end{tabular}

